Int. J. Dev. Biol. 53: 1385-1398 (2009)

doi: $10.1387 / \mathrm{ijdb} .072408 \mathrm{jd}$

\title{
Regulation and function of Spalt proteins during animal development
}

\author{
JOSE F. DE CELIS ${ }^{1}$ and ROSA BARRIO ${ }^{2}$ \\ ${ }^{1}$ Centro de Biología Molecular "Severo Ochoa". Universidad Autónoma de Madrid and Consejo Superior de Investigaciones Científicas, \\ Madrid and ${ }^{2}$ Functional Genomics, CIC bioGUNE, Bizkaia Technology Park, Derio, Spain.
}

\begin{abstract}
The genes of the spalt (sal) family play fundamental roles during animal development. The two members of this family in Drosophila, spalt (sal) and spalt-related (salr) encode Znfinger transcription factors that link the Decapentaplegic (Dpp)/BMP signalling pathway to the patterning of the wing. They are regulated by the Dpp pathway in the wing disc, and they were shown to mediate some of the morphogenetic activities of the Dpp/BMP4 secreted ligand. The sal genes were initially found by virtue of mutations that produce homeotic transformations in the head and tail of the Drosophila embryo. Since then, a number of other requirements have been associated to these genes in Drosophila, including morphogenesis of the respiratory system, cell fate specification of sensory organs and the differentiation of several photoreceptor cells, among others. Vertebrate sal orthologues (spalt-like/sall) have also important developmental roles during neural development and organogenesis, and at least two human sall genes are linked to the genetic diseases Townes Brocks Syndrome (TBS; SALL1) and Okihiro Syndrome (OS; SALL4). In this review, we will summarize the main characteristics of the sall genes and proteins, pointing out to the similarities in their developmental roles during Drosophila and vertebrate development.
\end{abstract}

KEY WORDS: spalt, gene regulation, organogenesis, embryonic development

\section{The Sall protein family}

Sall proteins are zinc finger transcription factors present from C. elegans, which harbours only one member of the family, to vertebrates, which generally present four spalt genes (sall1-4). The Drosophilagenome contains two paralogues, spalt (sa) and spalt-related (sali) which form part of a gene complex (Kuhnlein et al., 1994; Barrio et al., 1996). The more characteristic feature of Sall proteins is the presence of several zinc finger domains scattered along the protein (Fig. 1). Zinc finger domain 1 corresponds to the $\mathrm{C} 2 \mathrm{HC}$ class, and it is only present in the vertebrate homologues. The rest of the domains (2-5) correspond to $\mathrm{C} 2 \mathrm{H} 2$ zinc fingers arranged in pairs. The doublets are connected by a H/ $C$ link conserved throughout evolution, and the second finger from each pair contains a characteristic domain called Sal-box that is present in other zinc finger transcription factors. The third finger domain contains an associated finger, also highly conserved among orthologs. Another important domain characteristic of these proteins is a Glutamine rich region (polyQ), present from Drosophilato humans, which might be involved in protein-protein interactions among members of the family and between Sall and other proteins. The four orthologues vertebrate proteins, Sall1-4, display differences in the finger distribution, being Sall2 the more distant member of the family (Fig. 1; Kohlhase et al., 1996; Hollemann et al., 1996; Kohlhase et al., 1999a; Onuma et al., 1999; Ott et al., 1996; Buck et al., 2000; Ott et al., 2001; Ma et al., 2001; Kohlhase et al., 2002a; Ma et al., 2006). The nematode Sall protein, named Sem-4, shares common features with their homologues, like the finger domains 3 and 5 (Fig. 1; Basson and Horvitz, 1996; Photos et al., 2006). For a recent phylogenetic analysis of the Sall family, and a comprehensive update on the nomenclature of vertebrate orthologues, see a recent review by Sweetman and Munsterberg (2006).

There are several similarities among Sall activities in different organisms, such as their functions during embryonic development in a variety of processes including organogenesis, limb formation and cell fate assignment during neural development. In

Abbreviations used in this paper: BMP, bone morphogenetic protein; Dpp, decapentaplegic; OS, Okihiro Syndrome; TBS, Townes Brocks Syndrome.

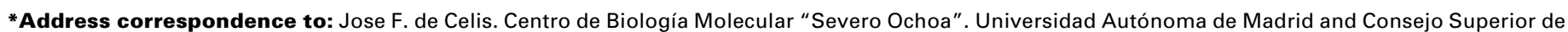

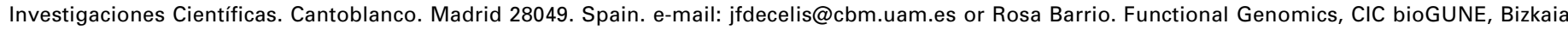
Technology Park. Building 801A, E-48160 Derio. Spain. e-mail: rbarrio@cicbiogune.es
}

Final author-corrected PDF published online: 27 October 2008.

ISSN: Online 1696-3547, Print 0214-6282

(C) 2008 UBC Press

Printed in Spain 

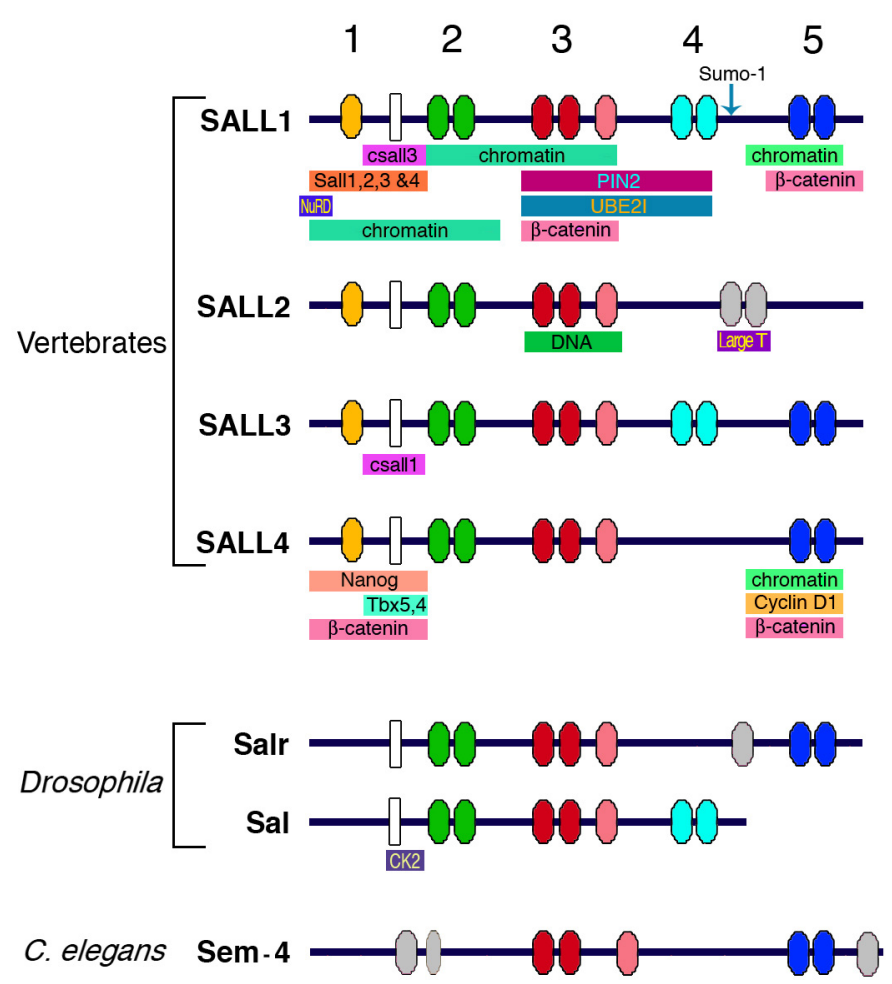

Fig. 1. Schematic representation of the main conserved domains present in Sall proteins. Coloured ovals numbered 1 to 5 represent the zinc finger domains from vertebrate, Drosophila and C. elegans Sall homologues. White rectangles represent the poly $Q$ regions. The arrow in Sall1 indicates the sumoylation site described for this protein. Coloured horizontal bars below each protein indicate the Sall-interaction domains with other proteins. Vertebrate data were collected from human, mouse, chicken and frog homologues (Bohm et al., 2007; Kiefer et al., 2002; Kieferet al., 2003; Koshiba-Takeuchiet al., 2006; Lauberth and Rauchman, 2006; Ma et al., 2006; Netzer et al., 2001; Netzer et al., 2002; Netzer et al., 2006; Li et al., 2001; Li et al., 2004; Onai et al., 2004; Sakaki-Yumoto et al., 2006; Sato et al., 2004; Sweetman et al., 2003; Trott et al., 2001; Wu et al., 2006; Yamashita et al., 2007).

this review we will summarize different aspects of Sall proteins and genes biology, with emphasis in their modes of regulation, their functions in proliferation and transcription, their developmental roles in different organisms and their association with several human genetic diseases.

\section{Regulation of sall gene expression}

Most of what is known about the regulation of sal/expression derives from studies in Drosophila saland salrgenes and in some vertebrate sal/members. A common aspect is that the expression of sal/genes depends on the activity of several signal transduction pathways (Table 1). In particular, the Wnt, FGF, Shh, EGFR and BMP pathways participate in the activation of sallexpression in different tissues and, in some cases, it has been shown that Sall proteins are key mediators of the function of these pathways during organogenesis and cell differentiation. The regulation of sal and salr in Drosophila has been studied extensively, and a number of tissue specific enhancers have been characterized
(Wagner-Bernholz et al., 1991; Kuhnlein et al., 1997; Chen et al., 1998; Barrio et al., 1999; de Celis et al., 1999; Guss et al., 2001; Barrio and de Celis, 2004). In this organism, the sal and salr transcription units are separated by $50 \mathrm{~kb}$ of non-coding DNA containing regulatory sequences. sa/is expressed during embryonic development in a variety of tissues, including the cellular blastoderm, posterior spiracles, trachea, oenocytes and cells in the central and peripheral nervous system (Fig. 2). The regions where salris expressed overlap in all these tissues, except in the early blastoderm where salris not expressed (Barrio et al., 1996). During larval development, sal andnsalr are expressed in the same cells in the wing, eye-antenna and haltere imaginal discs, as well as in the ring gland and central nervous system (Fig. 2). The structure of the sal and salr regulatory regions shows many similarities with those of other Drosophila gene complexes, such as the achaete-scute and Iroquois complexes (Ruiz-Gomez and Modolell, 1987; Gomez-Skarmeta et al., 1996). Thus, tissuespecific enhancers are scattered in the $50 \mathrm{~Kb}$ intergenic region and also in the 5 'and intronic regions of both genes (Fig. 2). The expression of the sa/and salrtranscripts is regulated by separate and, in some cases, shared cis-regulatory elements (Fig. 2). Enhancers that direct the expression of sa/in the blastoderm, wing and tracheae are some of the best characterized so far (Kuhnlein et al., 1997; Barrio and de Celis, 2004; Chen et al., 1998).

The detailed analysis of sal/salrregulatory elements in the wing disc showed an even greater complex organization, in that independent enhancers control the expression in different territories such as the wing pouch, thorax, hinge and pleura (Fig. 2; Barrio et al., 1999; de Celis et al., 1999). Interestingly, the expression in the thorax is also controlled by multiple elements affecting specific sub-domains. The organization of modular regulatory regions implies that the territories of sa/and salrexpression are, from the regulatory point of view, a mosaic of cell populations where different combinations of factors are responsible for the activation of each gene in different groups of cells. The expression of sal genes in the wing pouch is directly regulated by the Dpp pathway, acting through sal and salr independent enhancers. The Dpp pathway activates $s a$ lexpression in a central domain that is broader than the $d p p$ expression territory through a genomic region of 453 bp localized 5' of the sa/transcript (Barrio and de Celis, 2004). This enhancer integrates positive inputs mediated by the Dpp effectors Mad/Medea with the repressor activity of Brinker. The mechanism of repression by Brinker does not rely on competition with Mad-Medea overlapping sites, but on the existence of adjacent binding sites for Brinker and Mad/Med (Barrio and de Celis, 2004). Additional factors such as the T-box transcription factor Optomotor blind, the trithorax protein Ash2, the activator complex Vestigial/Scalloped and the repressor Groucho are also involved in the regulation of sa/in the wing blade (Guss et al., 2001; del Alamo Rodriguez et al., 2004; Angulo et al., 2004; Winter and Campbell, 2004; Hasson et al., 2005). The enhancer regulating salr expression in the wing blade has not yet been identified.

The regulation of sall genes expression in organisms other than Drosophila is less documented. However, some of the enhancers that direct tissue specific expression of human $S A L L 1$ have been identified by virtue of their sequence conservation, and have been tested experimentally in chicken and mice embryos (Table 1; Pennacchio et al., 2006; Izumi et al., 2007). A recurrent 
aspect in the regulation of vertebrate sal/genes is the involvement of signalling pathways in different developmental systems. For example, the expression of Xenopus Xsal/4 within the interdigital spaces suggests that BMP proteins are involved in regulating its expression in these territories (Neff et al., 2005). Similarly, the Msal/3gene from Medaka fish is expressed in most places where Hedgehog signalling is active, and Hedgehog regulates the expression of the gene at the midbrain-hindbrain organizer region (Koster et al., 1997). In this territory, FGF signalling is required to activate Msal/3 expression in response to Shh during Medaka development, and this regulatory relationship is also observed during the growth of the optic vesicle (Carl and Wittbrodt, 1999). The FGF pathway, now in collaboration with Wnt signalling, is also required for the activation of csall1 expression in chicken limb buds, where csal/1 is expressed in the apical ectodermal ridge and in the underlying distal mesenchyme (Farrell and Munsterberg, 2000). In these cells, a combination of Wnt3a and Wnt7a with FGF4 and FGF8, which are expressed in the apical ectodermal ridge, regulates csal/1 expression, whereas BMP function is also required to activate csall 1 in mesenchymal cells of the proximal limb (Capdevila et al., 1999; Farrell and Munsterberg, 2000). A recent analysis of the human $S A L L 4$ promoter region identified 367 bp located upstream of the ATG which sequence is extremely conserved in several vertebrates sal/4 genes. The observation that this region contains consensus-binding sites, which integrity is required for promoter activity in cell culture assays, for LEF/ TCF, a transcription factor mediating the response to canonical Wnt signalling, implies a direct effect of TCF on SALL4 expression (Bohm et al., 2006). Regulatory relationships between Wnt signalling and salare also observed in Drosophila and Xenopus. Thus, wingless, a Drosophila Wnt homologue, induces sal expression during tracheal development in the fly (Chihara and Hayashi, 2000; Ribeiro et al., 2004), and TCF3 is required for $X$ sall2 expression in the forebrain/midbrain at the early nerula stage in the frog (Onai et al., 2004). Interestingly, Xsall2 and human SALL1 modify the response to Wnt signalling, although Xsall2 antagonises Wnt signalling in vivo (Onai et al., 2004), and human SALL1 promotes Wnt signalling in cell culture assays (Sato et al., 2004). The function of Xsall2 is essential for the expression of the Pax6, Otx2, and Bf-1 genes in the forebrain/ midbrain region, and for the repression of the caudal genes En2, Pax2, Wnt1 and Gbx2. Xsall2 is also required for anterior expressions of two antagonistic effectors of Wnt signalling, GSK3 and Tcf3 (Onai et al., 2004).

The expression patterns of sal/family genes and the analysis of their regulation indicates that Sall function can not be universally assigned to specific signalling pathways, but rather that Sall has been adopted by different signalling pathways in different developmental contexts. Similarly, it appears that orthologues, as determined by degrees of conservation of sal/coding sequences, do not imply similarities of expression patterns.

\section{Function of Sall proteins in gene regulation}

The genetic approach to study sal function in Drosophila identified a number of developmental processes in which sa/and salrare involved. In addition, this approach also allowed in some instances to place sa/and salrinto genetic hierarchies, in which both upstream and downstream elements to sal/salrwere identified. Some of these aspects will be considered latter when addressing the specific roles of sal/salrin Drosophilatracheal and limb development. However, very few data are available in flies about the molecular mechanisms of Sal function, and no comprehensive analysis of Sal/Salr partners and target genes has been carried out yet. Thus, a direct interaction with DNA has only been shown in the case of Salr, which is able to bind an AT-rich sequence in the chorion gene $s 15$ promoter with the central zinc finger domain 3 (Table 2; Shea et al., 1990; Barrio et al., 1996).

TABLE 1

REGULATORY REGIONS AND DIRECT REGULATORS IDENTIFIED FOR SALL GENES

\begin{tabular}{|c|c|c|c|c|c|}
\hline Organism & Gene & Regulator & Enhancer & Function & References \\
\hline \multirow{6}{*}{ Human } & \multirow{4}{*}{ SALL1 } & ? & Tissue-specific enhancers $^{(1)}$ & $?$ & Izumi et al., 2007 \\
\hline & & SIX1 & Position -947 & Activation & Chai et al., 2006 \\
\hline & & WT1 & Position -2000 to +1 & Repression & Chai et al., 2006 \\
\hline & & $?$ & Tissue-specific enhancers ${ }^{(2)}$ & ? & Pennacchio et al., 2006 \\
\hline & SALL2 & Wilms Tumor-1 & Promotors $\mathrm{P} 1$ and $\mathrm{P} 2{ }^{(3)}$ & Repression & Ma et al., 2006 \\
\hline & SALL4 & Wnt (LEF1) & Position -249 to -218 & Activation & Boehm et al., 2006 \\
\hline \multirow{4}{*}{ Mouse } & Sall1 & Shh (GLI3) & Position -1344 to -1137 & Activation & Hu et al., 2006 \\
\hline & Sall3 & ? & T-DMR region & Repression & Ohgane et al., 2004 \\
\hline & \multirow{2}{*}{ Sall4 } & Nanog & ES enhancer & Activation & Wu et al., 2006 \\
\hline & & Sall4 & ES enhancer & Activation & Wu et al., 2006 \\
\hline \multirow{11}{*}{ Drosophila } & Sal/Salr & $?$ & Tissue-specific enhancers ${ }^{(4)}$ & $?$ & Barrio et al., 1999 \\
\hline & Sal/Salr & ? & Wing disc enhancers ${ }^{(5)}$ & ? & de Celis et al., 1999 \\
\hline & \multirow{9}{*}{ Sal } & Bcd, Cad, Tll, Hb & Blastoderm enhancer & Activation & Kuhnlein et al., 1997 \\
\hline & & $\mathrm{Hkb}, \mathrm{Kr}$ & Blastoderm enhancer & Repression & Kuhnlein et al., 1997 \\
\hline & & Kni/Knir & Trachea enhancer & Repression & $\begin{array}{l}\text { Kuhnlein et al., } 1997 \\
\text { Chen et al., } 1998\end{array}$ \\
\hline & & Ubx & sal 328 wing enhancer & Repression & $\begin{array}{l}\text { Galant et al., } 2002 \\
\text { Makhijani et al., } 2007\end{array}$ \\
\hline & & Sc & sal 328 wing enhancer & Activation & Guss et al., 2001 \\
\hline & & Dpp (Mad/Med) & sal 328 wing enhancer & Activation & Guss et al., 2001 \\
\hline & & Dpp (Med) & EcoRI-Ndel wing enhancer & Activation & Barrio and de Celis 2004 \\
\hline & & Dpp (Brk) & EcoRI-Ndel wing enhancer & Repression & Barrio and de Celis 2004 \\
\hline & & Antp & Eye/Antenna enhancer & Repression & Wagner-Bernholz et al., 1991 \\
\hline
\end{tabular}

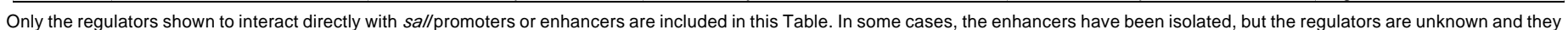

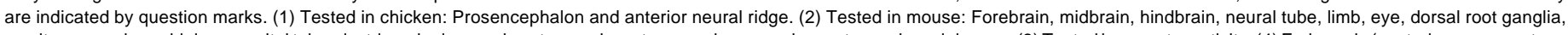

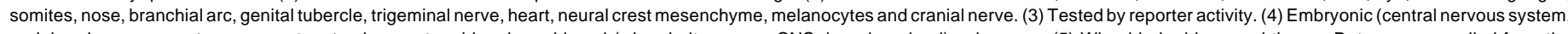

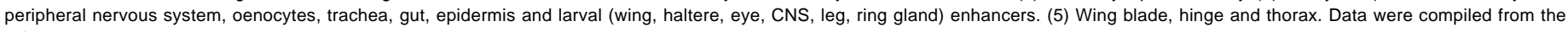
references indicated in the right-hand column. 
A
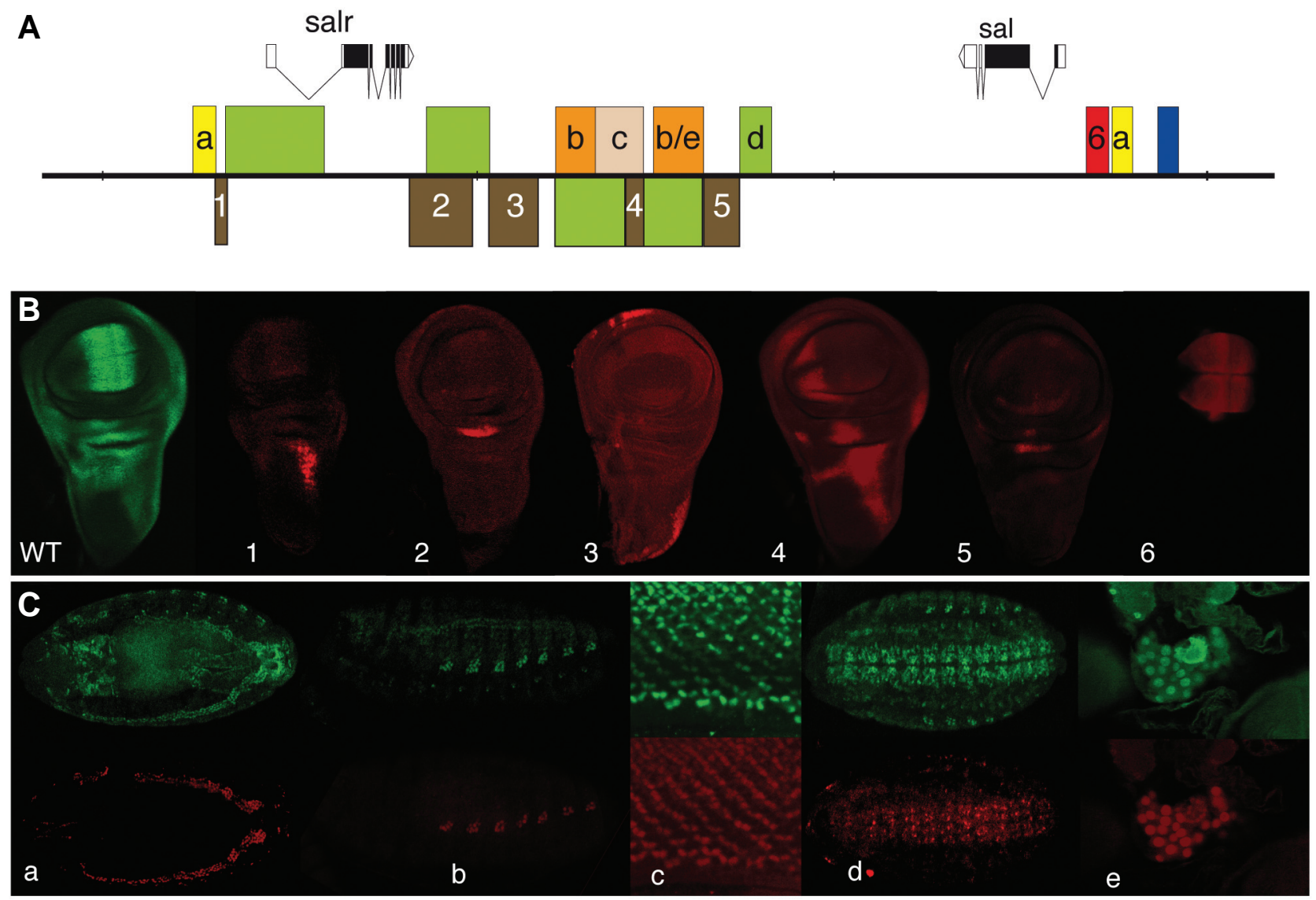

Fig. 2. Genomic structure of Drosophila sal genes and their regulatory modules. (A) Schematic representation of the sal-salr gene complex, showing the coding regions as black boxes, the non-coding RNA as empty boxes and the introns as connecting lines between boxes. Arrowheads indicate the direction of transcription. The coloured boxes above and below the genomic DNA (black line) represent regulatory modules identified in the sal complex (Kuhnlein et al., 1997; Chen et al., 1998; Barrio et al., 1999; de Celis et al., 1999; Barrio and de Celis, 2004). Yellow boxes correspond to regulatory regions driving reporter expression in the trachea (A), brown boxes in the wing imaginal disc (1-5), orange in the oenocytes (B) and the oenocytes and the ring gland (B/E), light brown in the eye imaginal disc (C), red in the wing blade (6) and blue in the blastoderm. (B) Expression of Sal in the wing imaginal disc (WT, green), and expression of $\beta$-Gal (red) in imaginal discs bearing reporter constructs for the regulatory regions shown in panel $A$ as brown boxes with numbers 1-5 and red box with number 6. (C) Each pair of pictures represent focal planes through Drosophila embryos showing the expression of Sal (above and in green in all pictures) and the expression of $\beta$-Gal driven by reporter constructs (below and in red). The letters in each picture correspond to the same letter code in panel A: the trachea (a), the oenocytes (b), the photoreceptors in the eye imaginal disc (c), the central nervous system (d) and the ring gland (e).

Similarly, CK2 kinase is the only protein reported to interact with Drosophila Sal (Trott et al., 2001). However, the biological relevance of these interactions has not yet been explored.

In contrast to the paucity of data concerning Sal molecular function in Drosophila, a wealth of data identifying Sall proteinprotein interactions, Sall subcellular localization and Sall transcriptional effects are stemming from the analysis of vertebrate sallgenes (Table 2). In what follows we will summarise some of the interactions identified for the sall genes and proteins 1, 2 and 4 , which taken together suggest that the variety of processes requiring Sall function can be accounted by the diversity of protein-protein and protein-DNA interactions in which Sall proteins are engaged (see Fig. 1).

Human SALL1 has been described as a transcriptional repressor in a number of experimental settings, most of them involving the regulation of heterologous promoters fused to reporter genes, and presents two possible mechanisms of repression (Nishinakamura et al., 2001; Netzer et al., 2001; Kiefer et al.,
2002; Sweetman et al., 2003; Netzer et al., 2006). First, the Nterminal part of the protein contains a 12 amino acids sequence that is able by itself to confer repression capacity and to interact with the Histone Deacetylase Complex NuRD (Kiefer et al., 2002; Lauberth and Rauchman, 2006). This interaction can be modified by phosphorylation of Sall1 (Lauberth et al., 2007). The NuRDinteraction domain is also found in other Sall homologues, including $C$. elegans Sem-4, and in transcription factors not related to the Sall family, but it is not present in the Drosophila Sal homologues. In the cases of human and murine SALL2/Sall2 and SALL4/Sall4, alternative spliced forms have been described that lack this repression domain that would function independently of the NuRD repression complex, although the functional role of these alternative forms is still unexplored. The $\mathrm{N}$-terminal part of the Sall1 shows localization to heterochromatin foci when fused to a nuclear localization signal, suggesting an association between transcriptional repression and protein location (Kiefer etal., 2002; Sato et al., 2004). 
The second repression mechanism is independent of the Histone Deacetylase Complex and requires the central region of the protein including the finger domains 2 and 3 (Netzer et al., 2001; Netzer et al., 2006). This region also shows localization in heterochromatin foci in murine cells. In addition, SALL1 can interact with PIN2, an isoform of telomere-repeat binding factor 1 (TRF1) (Netzer et al., 2001). TRF1/PIN2 binds to telomeres, suggesting a mechanism of repression for SALL1 by association to pericentromeric heterochromatin. Yet another region of the protein located in the C-terminal fingers has been described as important for the interaction with heterochromatin. This domain is particularly well conserved from Drosophilato humans and it has been reported to bind the major satellite DNA (Table 2; Yamashita et al., 2007).

Even though controversy exists about the identity of the domain involved in Sall-DNA interactions and the existence of different repression domains, it is interesting to speculate that Sall proteins might recruit remodelling factors to heterochromatin. In this context, Sall 1 is able to bind to $\beta$-catenin and activate synergistically a reporter construct responding to the Wnt signalling pathway (Sato et al., 2004). However, the domain of Sall1 that co-activates this reporter does not coincide with the $\beta$-catenin binding domain, but with the heterochromatin localization domain, indicating that Sall1 localization, and not its interaction with $\beta$-catenin, is the mediator of the interactions between Sall1 and the Wnt signalling pathway. In vivo, the role of human SALL1 as a transcriptional repressor has been shown during steroidogenesis in adrenal gland, where Sall 1 represses the expression of the enzymes 11-hydroxylase and aldosterone synthase, involved in the glucocorticoid and mineralocorticoid biosynthetic pathways under the modulation of Angiotensin II (Romero et al., 2007). In contrast, murine Sall1 is necessary for the activation of some kidney mesenchymal markers, consistent with its role in ureteric bud invasion (Nishinakamura et al., 2001). As in the case of the activation of Wnt signalling, the up-regulation of these genes might not be direct.

\section{Sall protein interactions}

The subcellular localization and transcriptional capacity of Sall proteins might be conditioned by posttranslational modifications. Thus, human SALL1 interacts with UBE2I, the homologue to ubiquitin conjugating enzyme 9, which promotes the binding of ubiquitin-like SUMO to target proteins. SALL1 is indeed sumoylated in vitro although the biological relevance of this modification remains to be explored (Netzer et al., 2002). Recently, it has been reported the capacity of protein kinase $\mathrm{C}$ to phosphorylate Sall1 at its repression motif, leading to the modification of its activity (Lauberth et al., 2007). No other posttranslational modifications have been described for other members of the Sall family. Most of the Sall proteins accumulate in the nucleus, with the exception of murine and chicken Sall3 and human SALL1 in certain cell types (Ma et al., 2001; Ma et al., 2002; Sweetman et al., 2003; Yamashita et al., 2007). SALL1 is engaged in interactions with other SALL family members and this could have dramatic functional consequences. Thus, cSall3 promotes changes in the subcel-
Iular localization of cSall1, which is retained in the cytoplasm in presence of cSall3 through protein-protein interactions via the conserved polyQ domains (Sweetman et al., 2003). The conservation of the polyQ region in Sall proteins opens the possibility of interactions among all the paralogues, which could to be important for the biological activity of the proteins.

The protein-protein interactions of Sall4 during embryonic development have also been studied in mouse and zebrafish limb development. In mice, Sall4 interacts with Tbx5, a T-box transcription factor involved in limb development, regulating the formation of the forelimb through the activation of FGF10 in a feed-forward mechanism (Koshiba-Takeuchi et al., 2006). In the hindlimb, an analogous interaction occurs with Tbx4, a factor necessary for hindlimb development. The interaction with Tbx5 seems to be important for the activation of Gja5in the heart where, at the same time, Sall4 interferes with the capacity of Tbx5 to activate Nppa. How Sall4 can achieve its role as transcriptional activator and repressor, and how this is related to its capacity to bind heterochromatin and promote the methylation of histones remains unclear.

\section{Sall proteins in stem cell and cancer biology}

Murine Sall1 has a role in maintaining cellular pluripotency and proliferation. Thus, renal primordial cells in the ureteric bud epithelium and metanephric mesenchyme are able to produce nephrons and collecting ducts when induced from pluripotent embryonic stem cells. Only cells expressing high levels of Sall1 can reconstitute a three-dimensional kidney structure in an organ culture setting, indicating that renal progenitors with multipotent capacity require Sall1 (Osafune et al., 2006; Yamamoto et al., 2006). In these cells, Sall1 is not required for generation or differentiation of renal progenitors but for their proliferation or survival (Osafune et al., 2006). Sall1, expressed in embryonic stem cells, seems to contribute to the activation of Oct4 (Zhang et al., 2006) and Sall1a is necessary for the activation of FGFR2 downstream of Tbx5 during zebrafish pectoral fin development (Harvey and Logan, 2006). Whether this activation capacity is direct or indirect remains to be investigated.

Mouse and human Sall2and SALL2genes have been reported as tumour suppressors in several conditions. Thus, Sall2 was

\section{TABLE 2}

\section{TARGET DNA SEQUENCES BOUND BY SALL PROTEINS}

\begin{tabular}{|c|c|c|c|c|c|}
\hline Organism & Gene & Target Gene & Regulatory Region & Sall Function & References \\
\hline \multirow{2}{*}{ Human } & SALL2 & p21 & -2610 to +51 promoter & Activation & Li et al., 2004 \\
\hline & SALL4 & Bmi-1 & -270 to -168 from enhancer & Activation & Yang et al., 2007 \\
\hline \multirow{4}{*}{ Mouse } & Sall1 & Major Satellite & ATAA A/T A/T A/T A/T & Repression ${ }^{(1)}$ & Yamashita et al., 2007 \\
\hline & \multirow{3}{*}{ Sall4 } & Nanog & $\begin{array}{l}\text { ES Enhancer; } \\
\text { TTAACATTCCTTTCCC }\end{array}$ & Activation & Wu et al., 2006 \\
\hline & & Sall4 & $\begin{array}{c}\text { ES Enhancer; } \\
\text { AATTATTGCCCGGATTTCAT }\end{array}$ & Activation & Wu et al., 2006 \\
\hline & & Pou5f1 & CR4C region & Activation & Zhang et al., 2006 \\
\hline Drosophila & Salr & s15 & TTATGAAAT & Repression ${ }^{(2)}$ & $\begin{array}{l}\text { Shea et al., } 1990 \\
\text { Barrio et al., } 1996\end{array}$ \\
\hline \multirow{2}{*}{ C. elegans } & \multirow{2}{*}{ Sem-4 } & egl-5 & $\begin{array}{l}\text { e5-1; TTGTGT } \\
\text { e5-2; TTGTCT } \\
\text { e5-3; ACACAA }\end{array}$ & Repression & Toker et al., 2003 \\
\hline & & mec-3 & $\begin{array}{l}\text { m3-1; AGACAA } \\
\text { m3-a; ACACAA } \\
\text { m3-3; ACACAA }\end{array}$ & Repression & Toker et al., 2003 \\
\hline
\end{tabular}

Only the sequences bound by Sall proteins are included. (1) Repression is inferred but not proved. (2) Repression is inferred, as Salr is not expressed at the same time than S15. Data were compiled from the references indicated in the right-hand column. 
identified in a large screen looking for targets of the Large $\mathrm{T}$ antigen from the highly oncogenic mouse polyoma virus ( $\mathrm{Li}$ et al., 2001). The interaction with Sall2 is important to suppress viral DNA replication and the growth of the virus (Li et al., 2001). Moreover, the presence of Sall2 in ovarian cancer cells inhibits their growth rate and their capacity to form colonies in soft agar. Some human ovarian carcinoma cell lines express low levels of $S A L L 2$ which, when re-introduced, results in a substantial reduction in the capacity of these cells to grow as tumours in nude mice. The control of cell growth and proliferation by SALL2 could be determined by its direct activation of $p 21$ and Bax (Table 2; Li et al., 2004).

Human SALL2 is also necessary for the activation of a number of genes expressed after serum deprivation, a situation in which there is inhibition of cell growth. These genes are repressed in many types of prostate, blood and lung cancers, and their repression can predict the increased risk of cancer progression and death in human breast cancers (Table 3; Liu et al., 2007). SALL2 is considered as an "early response gene" and it is necessary for the repression of the "middle response genes" that become super-induced when $S A L L 2$ is silenced, being unclear whether the activation and repression exerted by SALL2 on these genes is direct (Liu et al., 2007). SALL2 is also downregulated in other tumour types, like some lung carcinomas and adenocarcinoma of colon and prostate (Ma et al., 2001; Li et al., 2002). In contrast to the cases indicated above, where, as expected for a tumor suppressor, $S A L L 2$ is downregulated, $S A L L 2$ is upregulated in Wilm's Tumors and in Synovial Sarcoma cases (Table 3; Li et al., 2002; Nielsen et al., 2003). The molecular mechanisms underlying the roles of $S A L L 2$ as a tumour suppressor in certain types of cancers and its upregulation in sarcomas are still unknown.

Murine Sal/4 mRNA is inherited maternally and is abundant in the mice zygote. These transcripts are degraded during the two-cell stage. Zygotic transcription occurs after the four-cell stage, after which Sall4 mRNA levels continue to increase to the blastocyst stage (Zhang et al., 2006). The effects of Sall4 deficiency were studied using knockout mice and knockdown embryos (Zhang et al., 2006; Elling et al., 2006; Sakaki-Yumoto et al., 2006; Koshiba-Takeuchi et al., 2006; Warren et al., 2007). Homozygous mutant mice die during peri-implantation stages, due to lack of proliferation of the inner cell mass. In addition, Embryonic Stem Cells (ESC) derived from Sall4-null embryos proliferate poorly with no aberrant differentiation, and no embryonic nor extraembryonic endoderm stem cell lines can be established from Sall4 mutant blastocysts (Elling et al., 2006; Sakaki-Yumoto et al., 2006). The role of Sall4 on ESC maintenance can be achieved through its interaction with Nanog, a homeodomain transcription factor identified as a protein able to sustain pluripotency in murine ESCs. The complex Sall4Nanog could regulate the transcription of genes necessary for self-renewal, such as Sox 2 and Oct4, in addition to their own transcription, constituting a regulatory circuit (Table 2 and Fig. 3; Wu et al., 2006). Similarly to Oct4, the reduction in Sall4 expression results in re-specification of ESCs to the trophoblast lineage, and this change is related to the expansion of $\mathrm{Cdx} 2$ expression (essential to the trophectoderm lineage) into the Inner cell mass of the blastocyst (Zhang et al., 2006; Elling et al., 2006). The co-occupancy of Nanog binding sites by the complex Nanog-Sall4 results in the activation of Nanog downstream genes by the over-expression of Sall4 (Wu et al., 2006). In this experimental setting, the up-regulation of the trophectoderm lineage markers CDX2, HAND1 and GATA6 observed in the absence of human SALL4 could be indirect, occurring through the loss of POU5F1 expression (Zhang et al., 2006).

In concordance with its role in preserving the pluripotency of
A

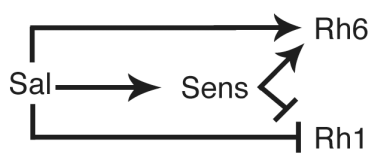

B

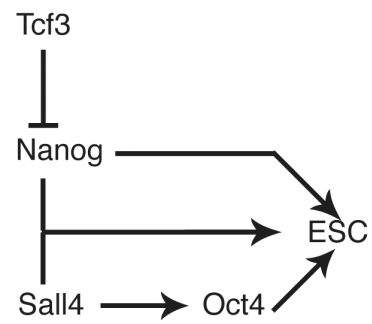

C

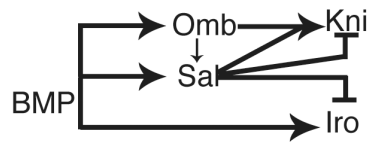

D

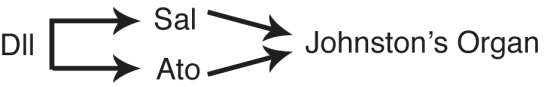

E

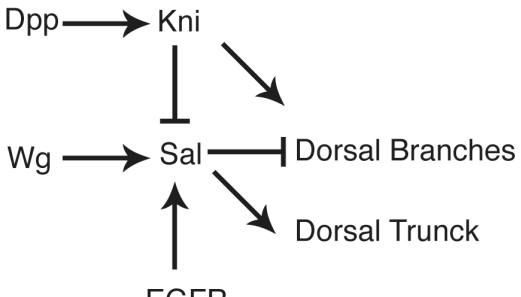

$\mathbf{F}$
Fig. 3. Schematic representation of genetic regulatory circuits in which Sall proteins and genes are involved during development. (A) Regulation by Sal and Senseless (Sens) of rhodopsin gene expression (Rh6 and Rh1) during the differentiation of the photoreceptor cell $R 8$ (modified from Domingos et al., 2004a). (B) Regulation of sal expression by Distal-less, and requirement of Sal and Atonal in the formation of the Drosophila auditory organ, the Johnston's organ (modified from Si Dong et al., 2003). (C) Regulation of Oct4 by Sall4, and requirement of Nanog, Oct4 and Sall4 during Embryonic stem cell maintenance and Epiblast development (modified from Zhang et al. (2006) and Pereira et al. (2006). (D) Regulation of sal expression by Wg, EGFR and Dpp signalling during trachea development and its function in the specification of the dorsal trunk (modified from Kühnlein and Schuh (1996); Chen et al. (1998) and Chihara and Hayashi (2000)). (E) Regulatory interactions between the Dpp (BMP) downstream transcription factors Sal, Kni, Omb and Iro during Drosophila wing blade development (de Celis and Barrio, 2000; del Alamo Rodriguez et al., 2004; Cook et al., 2004). (F) Regulatory interactions occurring during Butterfly eye spot formation involving Sal, Engrailed and the candidate eyespot signalling molecules BMP and Wnt homologues. The dashed line indicates that Sal only represses En expression in some species, but not in others, generating either concentring rings or nested domains of Sal and En expression. Modified from Brunetti et al. (2001) and Monteiro et al. (2006). 
stem cells in mice, the Xenopus homologue, X/sall4, was identified in a subtracted limb regeneration screen (King et al., 2003). X/sal/4 transcripts are expressed during the early and middle phases of limb development and also in the fore- and hindlimb during regeneration-competent stages, suggesting that its activity could maintain blastema cells in an undifferentiated state (Neff et al., 2005). Similarly, the chicken homologue csal4 seems to keep neural crest cells in an undifferentiated stage (Barembaum and Bronner-Fraser, 2004). All these vertebrate homologues are expressed in the growing tail tip region rich in undifferentiated cells (Kohlhase et al., 2002a; Barembaum and Bronner-Fraser, 2004; Neff et al., 2005). The expression of human and murine $S A L L 4$ Sall 4 during adulthood is restricted to testis and ovaries (Kohlhase et al., 2002a; Kohlhase et al., $2002 b)$. Furthermore, microarray analysis shows that in the ovaries of newborn mice mutant for Nobox, a homeobox gene expressed in oocytes and required during oogenesis, Sal/4 is drastically downregulated, coinciding with a rapid loss of postnatal oocytes (Choi et al., 2007).

The lack of proliferation observed in Sal/4 null mutant mouse cultured blastocysts and embryos in vivo (Sakaki-Yumoto et al., 2006) might be related to the inefficient G1/S transition observed in ESCs, which could be linked to the interaction of Sall4 with CyclinD1 (Bohm et al., 2007). A possible role of Sall4 in promoting cell proliferation could also be related to the expression of human $S A L L 4$ in certain type of tumours. Accordingly, $S A L L 4$ is upregulated in acute myeloid leukaemia (Table 3 ). The constitutive expression of SALL4 may enable leukaemic blasts to acquire stem cell properties, such as self-renewal and/ or lack of differentiation, and become leukaemia stem cells (Ma et al., 2006; Cui et al., 2006). This is probably achieved through the activation of the $\mathrm{Wnt} / \beta$-catenin signalling pathway, as shown by the up-regulation of the Wnt targets c-Myc and CyclinD1 in leukaemic cells where SALL4 is over-expressed (Ma et al., 2006), or by the activation of the polycomb gene Bmi-1, which plays an essential role in regulating adult, self-renewing hematopoietic stem cells and leukaemia stem cells (Yang et al., 2007). The activation of $B m i-1$ is associated to increased levels of histone methylation in the $B m i-1$ promoter, but the mechanism relating the over-expression of $S A L L 4$ and the hypermethylation of histones is still unknown (Yang et al., 2007). A different role for SALL4 during tumourigenesis might be achieved through its role as a "caretaker" of chromosomal stability, which could be related to the capacity of SALL4 to bind to heterochromatic regions through its most C-terminal finger pair (Sakaki-Yumoto et al., 2006; Bohm et al., 2007). Human $S A L L 4$ is epigenetically silenced in colorectal cancer aneuploid cells where $S A L L 4$ promoter is more frequently hypermethylated than in diploid cells (Habano et al., 2007). Thus, the absence of SALL4 might influence tumourigenesis by destabilization of chromosomes, but its upregulation might influence tumourigenesis by promoting proliferation.

\section{Sal proteins in cell specification and morphogenesis}

sall genes are required for multiple developmental processes, suggesting that they engage in a variety of interactions and modify the expression of target genes in a context-dependent manner. We have attempted to classify these processes into several categories that include sal/invertebrate and vertebrate members, and will discuss in more detail some representative examples.

\section{Cell fate assignment}

The Drosophila saland salrgenes, and also several members of the sal/family in other organisms, participate in a variety of cell-fate decisions during development, controlling the distinction between alternative cell fates or the implementation of a particular program of cell differentiation. Examples of the former are the function of the sem-4 ortologue in C. elegans during the specification of touch receptor neurons (Mitani et al., 1993), and the function of Drosophila sal genes in the formation of the oenocytes and strech receptors (Rusten et al., 2001; Elstob et al., 2001). In the first case Sem-4 regulates, by repression, the expression of the Hox gene eg/-5 and the LIM homeobox gene mec-3. These interactions are direct, because Sem-4 binds to a common motif present in the mec-3and eg/-5promoters (Table 2; Toker et al., 2003). Sem-4 also regulates the expression of the Hox genes lin-39 and, in the absence of sem-4, the secondary vulval cell lineage is not correctly specified (Grant et al., 2000). The relationships between $\mathrm{Sal}$ and Hox functions in the specification of cell identities is a common aspect of Sal proteins also observed in Artemia and Drosophila, although the interactions between sal and Hox genes vary in different developmental systems. Thus, the Artemia sa/orthologue is expressed in the presegmental growth zone and in the segments that emerge from this zone (Copf et al., 2006). The loss of sa/function, caused by RNA interference, results in a variety of homeotic transformations associated with the de-repression of different Hox genes in the corresponding segments, indicating that Sal regulates Hox gene expression (Copf et al., 2006). Because Artemia sa/is expressed in all segments, and the observed homeotic transformations in knockdown animals are variable and stochastic, it was suggested that Sal function is related to the maintenance of spatial domains of Hox expression acting in transcriptional repression by chromatin modifications (Copf et al., 2006).

In contrast to this role in the maintenance of Hox expression, the Drosophila sa/gene acts downstream of different Hox genes

TABLE 3

\section{SALL PROTEINS INVOLVED IN HUMAN DISEASES}

\begin{tabular}{|c|c|c|c|}
\hline Gene & Disease & Expression & References \\
\hline \multirow{7}{*}{ Sall1 } & Townes Brocks Syndrome & Mutated, Deleted & Kohlhase et al., 1996 \\
\hline & Trophoblast tumours & Upregulated & Ma et al., 2002 \\
\hline & Sex hormone-producing tumours & Upregulated & Ma et al., 2002 \\
\hline & Wilm's Tumour & Upregulated & Ma et al., 2002 \\
\hline & Testicular carcinoma & Upregulated & Hoei-Hansen et al., 2004 \\
\hline & Congenital Renal Dysplasia & Downregulated & Jain et al., 2007 \\
\hline & Congenital Obstructive Nephropathy & Downregulated & Liapis, 2003 \\
\hline \multirow{5}{*}{ Sall2 } & Synovial sarcomes & Upregulated & $\begin{array}{c}\text { Niesen et al., } 2003 \\
\text { Subramaniam et al., } 2006\end{array}$ \\
\hline & Wilm's Tumour & Upregulated & Liet al., 2002 \\
\hline & Prostate and Breast cancer & Downregulated & Liu et al., 2007 \\
\hline & $\begin{array}{l}\text { Lung carcinomes } \\
\end{array}$ & Downregulated & Ma et al., 2001b \\
\hline & $\begin{array}{c}\text { Colon and Prostate adenocarcinome } \\
\text { Ovarian carcinome }\end{array}$ & $\begin{array}{l}\text { Downregulated } \\
\text { Downregulated }\end{array}$ & Li et al., 2004 \\
\hline \multirow{4}{*}{ Sall4 } & Okihiro Syndrome & Mutated, Deleted & $\begin{array}{l}\text { Al-Baradie et al., } 2002 \\
\text { Kolhase et al., } 2002\end{array}$ \\
\hline & Acute Myeloid Leukemia & Upregulated & $\begin{array}{l}\text { Ma et al., } 2006 \\
\text { Cui et al., } 2006 \\
\text { Yang et al., } 2007\end{array}$ \\
\hline & Lymphoblastic leukemia/lymphomes & Upregulated & Cui et al., 2006 \\
\hline & Aneuploid sporadic colorectal cancer & Downregulated & Habano et al., 2007 \\
\hline
\end{tabular}

Only the first references to TBS and OS are included. Data were compiled from the references indicated in the right-hand column. 
in the haltere, labial and antennal imaginal discs. The distinction between wing and haltere relies in the function of the Ultrabithorax $(U b x)$ Hox gene. Among several other target genes, Ubx directly repress salexpression in the haltere, suppressing the positive input of Dpp on sa/and contributing to the differences between these two structures (Weatherbee et al., 1998). Similarly, the Hox proteins Proboscipedia and Sex combs reduced direct the development of the proboscis by repressing sa/expression in the labial disc (Abzhanov et al., 2001). In the antennal disc salalso acts downstream of genes specifying segmental identity, but its expression is activated rather than repressed by the combination of Distal-less and Homothorax (Dong et al., 2000). Interestingly, reminiscent to the loss of hearing associated to human $S A L L 1$ mutations (see below), loss of saland salr in the antennal disc causes a severe reduction in the major Drosophilaauditory organ, the Johnston'n organ, and is associated with deafness (Dong et al., 2003). Finally, Drosophila Sal proteins also have homeotic functions independent of Hox genes during embryogenesis, acting to promote head versus trunk development (Jurgens, 1988).

The function of $s a /$ genes in specifying cell types does not always relies in their relationships with Hox genes. A clear example of a direct role of Sal proteins in cell differentiation occurs during Drosophila eye development, where Sal influences the formation of the R3, R4, R7 and R8 photoreceptors (Fig. 3A). Thus, $S a l$ is required for the specification of $R 7$ and the expression of R7 specific markers, the terminal differentiation of R8 and the regulation of photoreceptor specific rhodopsins, the correct specification of the R3/R4 pair of cells and establishment of planar cell polarity. Finally, Sal expression needs to be repressed latter in these cells to inhibit their transformation to R7 fate (Mollereau et al., 2001, Domingos et al., 2004a; Domingos et al., 2004b). A similar function in cell-fate specification can be operative in many cell populations during neural system development, because sal and sal/genes are expressed predominantly in the developing nervous system in a variety of organisms. An interesting example of Sal functions in cell fate decisions is the formation of a particular type of sensory organs in Drosophila, where Sal operates as a switch between two cell types induced by EGFR activity, the oenocytes and the precursors of the pentascolopodial sensory organ. This organ is formed by five sensory units derived from five chordotonal organ precursors (COPs; Gould et al., 2001). The oenocytes form around the most dorsal COP and express high levels of Sal. The absence of Sal results in the lack of oenocytes accompanied by the formation of extra COPs, indicating that Sal is necessary to promote oenocyte formation and to restrict the number of COPs at the same time (Rusten et al., 2001; Elstob et al., 2001). This role of Sal is reminiscent of the role of Sall4 in the decision between inner cell mass and trophoblasts in the mouse (Elling et al., 2006).

\section{Regional specification}

Another common aspect of sall functional requirements in different organisms occurs during the subdivision of a cell population into smaller developmental units, which we refer to as "regional specification". This feature of sall function was first identified for the Drosophila saland salrgenes during the growth and patterning of the wing imaginal disc, an epithelial tissue that differentiate during metamorphosis the fly wing and thorax. The Sal/Salr proteins act in the wing blade as transcription factors conferring regional identity to the central part of the wing, linking the activity of the secreted molecule Dpp to pattern formation (de Celis et al., 1996). Thus, saland salr are expressed in a central domain of cells in the wing region of the disc, where they participate to the patterning of the wing blade (Fig. 3E). The Dpp pathway directly regulates the expression of saland salrin this territory, and they direct the localisation of characteristic wing pattern elements, the veins, by regulating the expression of the vein-specific genes of the knirps and Iroquois gene complexes (Fig. 3E; de Celis and Barrio, 2000). In the case of the Iroquois genes, Sal/Salr repress their expression in all cells not exposed to Hedgehog signalling, confining Iroquois expression to the posterior L5 provein territory. The relationship between Sal/Salr and the knirps genes is more complex, because their expression is activated in the domain where Sal/Salr levels are lower in anterior cells, and repressed by higher levels of Sal/Salr in the rest of the wing (de Celis and Barrio, 2000). In addition to its patternpromoting function, Sal and Salr are also required for cell viability, cell proliferation and epithelial integrity of the cell population where they are expressed (de Celis et al., 1996; Milan et al., 2002).

Several vertebrate Sall proteins are also expressed in the growing limbs, where they could also function to provide territorial identities to mesenchymal cell populations. Xenopus Xsal/4 is expressed in developing hind- and forelimbs in a dynamic temporal and spatial pattern that first is confined to the distal half of the limb bud, later is excluded from proximal-posterior and anterior regions of the bud, and finally becomes restricted in the future autopod to six interdigital domains (Neff et al., 2005). In chicken, csall1 and csall2 are also expressed in developing limbs (Farrell and Munsterberg, 2000; Farrell et al., 2001). The expression of csall1 is observed continuously through the distal limb mesenchyme and the apical ectodermal ridge (Capdevila et al., 1999; Farrell and Munsterberg, 2000). In contrast, csall2 displays a dynamic temporal and spatial pattern of expression that is differentially regulated in wing and leg primordia, being in both cases detected mainly in the posterior-distal mesenchyme (Farrell et al., 2001). In zebrafish, sall1a and sall4 are expressed in developing limb-like structures, the pectoral fins (Camp et al., 2003). The expression of sall 4 is first detected through the fin bud mesenchyme, and as its development proceeds, sall 4 transcripts are accumulated at the distal tip of the fin. Loss-of-function experiments using sal/4 morpholinos showed that this gene is required for the outgrowth of pectoral fins and the formation of its distal structures (Harvey and Logan, 2006). The gene sall1a is expressed in both the mesenchyme and the ectoderm (Camp et al., 2003; Harvey and Logan, 2006), with highest levels in the distal fin bud in a pattern comparable with the observed for sall1 in limb buds in mouse and chick (Farrell and Munsterberg, 2000; Buck et al., 2001). Similar to sall4, sall/a morphants develop truncated and often absent pectoral fins, indicating a requirement for fin bud outgrowth. In the double sal/4/sal/1amorphant embryo the fin bud is initially formed, but it fails to develop further due in part to the absence of FGF10 expression (Harvey and Logan, 2006). Similarly to other vertebrate orthologs, mouse Sall1 is also expressed in the developing limb, in a pattern that evolves during limb development from most of the mesenchyme and ectoderm to the tips of the digits and interdigital territories (Buck et al., 2001). Interestingly, distal limb defects, such as bifid thumbs and loss of 
thumbs, as well as polydactyly are characteristic abnormalities of TBS and OS (Kohlhase et al., 1998; Kohlhase et al., 2002b; AlBaradie et al., 2002 and see below).

A conceptually similar function of Sall proteins during regional specification is observed during the development of eyespots in the wings of butterflies. Eyespots are pigmentation patterns characteristic of many butterflies and moth wings. The formation of the eyespot is controlled from its centre, the focus, which induces surrounding cells to acquire different colour fates. In Bicyclus anynana, the Sal homolog is expressed in the focus from its onset, and later in several concentric rings outside the focal region (Brunetti et al., 2001; Monteiro et al., 2006). Interestingly, the Engrailed homolog is expressed in an outer ring outside the domain of Sal expression, suggesting that regulatory interaction between Sal and Engrailed orthologs participate in the elaboration of gene expression domains. This interaction is reminiscent to the repression of Iroquois expression by Sal observed in the Drosophilawing, and in both case leads to the creation of adjacent domains of gene expression (Fig. 3E-F).

\section{Organogenesis}

During organogenesis, cells from distinct origins, or with different developmental programs, must be integrated to form functional structures. The activity of sal/genes is required in several internal organs such as the heart and kidney in vertebrates and the tracheae (respiratory tubes) in Drosophila. A conserved feature among vertebrates is the expression of sallgenes during the development of the kidney. Thus Xenopus Xsall $4 b$ and zebrafish sall1a, are expressed in the pronephric ducs, and chicken csall 3 is expressed in the mesonephros (Onuma et al., 1999; Farrell et al., 2001; Camp et al., 2003). The function of sall during kidney development has been mainly studied using Sall1 knockout mice. The development of the vertebrate metanephros implies mutual inductive interactions between the ureteric bud and the metanephric mesenchyme. In this manner, the invasion of the mesenchyme by the ureteric bud epithelia, and its accompanying branching morphogenesis to form the collecting ducts and urethra, is induced by the mesenchyme, and reciprocally, the ureteric bud induces mesenchymal aggregation around the bud tip and mesenchyme-to-epithelial conversion to form the renal vesicle (Dressler, 2006). The Sall1 mice gene is exclusively expressed in the metanephric mesenchyme prior to bud invasion, and this expression is maintained in the mesenchyme condensing around the ureteric bud tips. The function of Sall1 is required to promote ureteric bud invasion, which failure causes a subsequent collapse of tubule differentiation by the mesenchyme. In this manner, in Sal/1-null mice the metanephric mesenchyme and the ureteric bud are formed, but the bud fails to invade the mesenchyme (Nishinakamura et al., 2001). FGF signalling could regulate the expression of Sall1 in the early metanephric mesenchyme, as double mutant FGFR1/FGFR2 mice display renal aplasia and the expression of Sall 1 is absent from the rudimentary mutant metanephric mesenchyme (Poladia et al., 2006). It is not clear what is the exact role of Sall1 in the mesenchyme, because direct targets activated or repressed by Sall 1 in this tissue have not yet been identified. In contrast to the requirement of Sall1 during vertebrate kidney development, the function of Drosophila sal genes is not operative in the fly kidney equivalent, the Malpighian tubules, even though the formation of this structure also includes interactions between ectodermal epithelial buds and mesenchymal mesodermal cells (Denholm et al., 2003).

The formation of the Drosophila tracheal system involves a number of cellular activities similar to vertebrate kidney formation, such as oriented cell migration, branching morphogenesis and inductive signalling from independent tissues (Metzger and Krasnow, 1999; Affolter and Shilo, 2000). Trachea formation is initiated from ectodermic placodes that invaginate into the underlying mesoderm and undertake a complex branching pattern to form a three-dimensional network of tubes. Loss of sa/function results in a variety of phenotypes including the formation of ectopic placodes and the lack of the dorsal trunk (Kühnlein and Schuh, 1996). The first phenotype suggest an early role of Sal in suppressing tracheal fate, whereas the loss of the dorsal trunk is due to faulty cell specification within the tracheal placodes (Kühnlein and Schuh, 1996; Franch-Marro and Casanova, 2002). The failure to form the dorsal trunk in sa/mutants, caused by the lack of antero-posterior migration and fusion into a trunk of the dorsal trunk primordia, is reminiscent of the requirement of Sall1 in promoting ureteric bud invasion, although during tracheal development the requirement of Sal is cell autonomous in the migrating cells. Wnt and EGFR signalling induce and maintain, respectively, the expression of Sal in the dorsal part of all tracheal placodes, in a region that initially encompasses the primordia of the dorsal branch and the dorsal trunk (Fig. 3D; Chihara and Hayashi, 2000). Latter, Sal expression is restricted to the dorsal trunk primordia, where it is present after the connection between the posterior and anterior dorsal trunk branches from adjacent placodes (Kühnlein and Schuh, 1996; Wappner etal., 1997; Chen et al., 1998). The downregulation of Sal in the dorsal branch primordia is mediated by repression of Knirps, acting directly on a sa/regulatory element (Chen et al., 1998). The repression of sal expression by Knirps is a requisite for normal dorsal branch morphogenesis. In this manner, Sal and Knirps became expressed to adjacent territories, the primordia of the dorsal branch and the dorsal trunk, which will follow different developmental fates (Fig. 3; Chen et al., 1998; Franch-Marro and Casanova, 2002).

\section{Sall genes in disease}

Human SALL1 mutations are associated to TBS, an autosomal dominant group of malformations characterized by imperforate anus, triphalangeal and supernumerary thumbs, dysplastic ears and sensorineural hearing loss (Kohlhase et al., 1998; Surka et al., 2001; reviewed by Powell and Michaelis, 1999). So far, 56 family mutations in SALL1 associated to TBS disorders are characterised (Botzenhart et al., 2007 and references therein), most of them located between the polyQ domain and the Cterminal part of the zinc finger domain 2 . Therefore, it is likely that the TBS patients express a truncated protein able to interact to other SALL proteins via the poly $Q$ region and block their function. Only two of the reported cases would produce truncated proteins lacking the glutamine-rich domain, although in both cases the mutant proteins contain the initial $\mathrm{C} 2 \mathrm{HC}$ zinc finger motif and the $\mathrm{N}$-terminal repressor domain, indicating that the glutamine domain is not absolutely required for typical TBS symptoms (Kohlhase et al., 1999b; Botzenhart et al., 2007). Some patients present deletions of the whole $S A L L 1$ gene and, in fact, they show a rather mild TBS phenotype, reinforcing the idea that the haploinsuffi- 
ciency is not enough to cause the severe classical TBS symptoms (Borozdin et al., 2006). Confirming the role of Sall1 in kidney formation, $S A L L 1$ expression is reduced in patients with congenital dysplastic kidneys, a major cause of renal failure in infants (Jain et al., 2007), as well as in congenital obstructive nephropathy, a common disease affecting foetuses and young children (Table 3; Liapis, 2003). Mice homozygous for Sall1 show kidney agenesis and die in the perinatal period. The abnormal kidneys result from incomplete ureteric bud outgrowth, deficient mesenchyme tubule formation and apoptosis of the mesenchyme (Nishinakamura et al., 2001; reviewed by Nishinakamura and Osafune, 2006). However, in contraposition to the dominant effect shown in human TBS patients, heterozygous Sal/1 mutants do not show any phenotype. Interestingly, the expression in mice of truncated Sal/1/lacking all the double zinc fingers but preserving the $\mathrm{N}$-terminal part of the protein, recapitulate remarkably all the abnormalities found in human TBS, supporting the idea of TBS being caused by the dominant negative effect of truncated SALL1 proteins (Kiefer et al., 2003).

Mutations in SALL4 are involved in the autosomal dominantly inherited human OS (Al-Baradie et al., 2002; Kohlhase et al., $2002 b)$. This malformation syndrome is characterized by radial defects of the upper limbs and by Duane anomaly, a rare form of strabismus, also associated with hearing loss. There is large intra- and interfamilial variability in the clinical features of patients with SALL4 mutations and patients can be miss-diagnosed, being the mutational analysis of $S A L L 4$ important for the interpretation of the symptoms (Kohlhase et al., 2002b; Brassington et al., 2003; Borozdin et al., 2004; Kohlhase and Holmes, 2004; Kohlhase et al., 2005). In contrast to SALL1 mutants causing TBS, the mutations founded in $S A L L 4$-related syndromes do scatter along the gene, indicating that the clinical features are caused by loss-offunction and haploinsufficiency, rather that by a dominant negative effect of truncated proteins (Borozdin et al., 2004).

Some OS patients also show severe growth retardation, also seen in patients affected by TBS that might indicate pituitary dysfunctions associated with SALL4 mutations (Kohlhase et al., 2005; Miertus et al., 2006). A plausible explanation for the features shared by OS and TBS is that SALL4 can interact with SALL1. Thus, the C-terminally truncated SALL1 protein produced in TBS patients could dimerise with SALL4, interfering with the binding of SALL4 to heterochromatin in a dominant-negative manner (Sakaki-Yumoto et al., 2006). Therefore, some phenotypes observed in SALL1 truncations could be explained by the reduction of SALL4 function. Homozygous Sal/4 mutant mice dye during peri-implantation stages due to lack of proliferation of the inner cell mass (Zhang et al., 2006; Elling et al., 2006; SakakiYumoto et al., 2006; Warren et al., 2007). Interestingly heterozygous Sall4 mice reproduce most of the features of the OS. This syndrome can also be reproduced in zebrafish, where Sall/4 is not required for the initiation of development but for outgrowth of the pectoral fins primordia (Harvey and Logan, 2006). The zebrafish model allows distinguishing between features typical of OS versus Holt-Oram Syndrome, caused by mutations in the T-box TBX5, demonstrating that these models are extraordinary valuable to understand the clinical consequences of $S A L L$ mutations.

In contrast to SALL1 and 4, mutations in SALL2 and 3 have not been associated to any genetic syndrome, although $S A L L 3$ maps in the chromosomal region associated to the $18 q$ Deletion Syn- drome characterized by mental retardation, short stature, hypotonia, hearing impairment, and foot deformities (Kohlhase et al., 1999a), and $S A L L 2$ maps to a chromosomal region related to haploinsufficiency in some ovarian carcinomas (Kohlhase et al., 1996). Murine Sall2 is dispensable for normal development, showing no effects in the tissues where it is expressed. Moreover, Sall2removal does not exacerbate the kidney defects caused by Sall1 mutation. Despite its classification as a tumour suppressor gene, homozygous mutant mice did not show spontaneous tumour formation for more than 1 year after birth (Sato et al., 2003). The most prominent expression domain of Sall2 is the brain, raising the possibility for a function in this organ (Kohlhase et al., 2000). However, no behavioural defects or any other anomalies were reported.

Sal/3 deficient mutant mice present malformation in organs necessary for normal feeding behaviour, such as the palate, the epiglottis, the tongue, and the corresponding cranial nerves. Homozygous animals die shortly after birth because their inability to feed properly, but the heterozygotes are fertile and indistinguishable from wild type (Parrish et al., 2004). In a similar way to Sall4, Sall3 could also be required during the specification of embryonic versus throphoblast stem cells (Ohgane et al., 2004).

\section{Concluding remarks}

The understanding of Sall proteins function and sall genes regulation is still incomplete, but the use of different experimental models and the combination of biochemical and genetic approaches is unravelling many significant aspects of their biology. The existence of many Sall interacting proteins and the likely variety of Sall mechanisms of transcriptional regulation confers a great versatility to Sall function. Similarly, it is expected that the existence of multiple cis-regulatory regions in sall genes is a general trend, contributing to the deployment of sallexpression in multiple developmental contexts under the regulation of a diversity of transcriptional regulators. These two characteristics most likely determine the multiple requirements identified for Sall function during multicellular development and the variety of tissues where they are expressed. Future research avenues into Sall biology will certainly include the identification of additional Sall-interacting proteins, the analysis of Sall posttranscriptional modifications and their functional consequences, and the study of the molecular mechanism of transcriptional regulation. The identification of Sall downstream genes, and the characterisation of their mode of regulation are expected to contribute fundamentally to the understanding of the biological requirements of Sall during animal development.

\section{Acknowledgements}

We are grateful to F. C. Kafatos, A. Garcia-Bellido and M. Ashburner in which laboratories we carried out a great part of our research on the Drosophila spalt gene complex. We thank J. D. Sutherland, A. Talamillo, $J$. Sánchez, R. Cantera and T. E. Rusten for the critical reading of this manuscript, and the criticism from two anonymous reviewers that helped to improve the paper. R.B. would like also to acknowledge the continuous contribution and inspiration from her colleagues $R$. Cantera and T. E. Rusten and the help with the protein analysis from L. Sánchez. J.F.dC. is supported by an institutional grant from the Ramón Areces Foundation to the Centro de Biologia Molecular "Severo Ochoa" and by the Ministerio de Educación y Ciencia (BFU2006-06501). R.B. belongs to the Cajal 
Program (MEC) and is recipient of grants from the Spanish Ministry of Education (BFU2005-00257), the Department of Industry, Tourism and Trade of the Government of the Autonomous Community of the Basque Country (Etortek Research Programs 2005/2006) and from the Innovation Technology Department of the Bizkaia County.

\section{References}

ABZHANOV, A., S. HOLTZMAN and T. C. KAUFMAN (2001) The Drosophila proboscis is specified by two Hox genes, proboscipedia and Sex combs reduced, via repression of leg and antennal appendage genes. Development 128: 2803-2814.

AFFOLTER, M., and B. Z. SHILO (2000) Genetic control of branching morphogenesis during Drosophila tracheal development. Curr Opin Cell Bio/12: 731-735.

AL-BARADIE, R., K. YAMADA, C. ST HILAIRE, W. M. CHAN, C. ANDREWS et al. (2002) Duane radial ray syndrome (Okihiro syndrome) maps to 20q13 and results from mutations in SALL4, a new member of the SAL family. Am J Hum Genet 71: 1195-1199.

ANGULO, M., M. COROMINAS and F. SERRAS (2004) Activation and repression activities of ash2 in Drosophila wing imaginal discs. Development 131: 49434953.

BAREMBAUM, M., and M. BRONNER-FRASER (2004) A novel spalt gene expressed in branchial arches affects the ability of cranial neural crest cells to populate sensory ganglia. Neuron Glia Bio/1: 57-63.

BARRIO, R., and J. F. DE CELIS (2004) Regulation of spalt expression in the Drosophila wing blade in response to the Decapentaplegic signaling pathway. Proc Natl Acad Sci USA 101: 6021-6026.

BARRIO, R., J. F. DE CELIS, S. BOLSHAKOV and F. C. KAFATOS (1999) Identification of regulatory regions driving the expression of the Drosophila spalt complex at different developmental stages. Dev Bio/215: 33-47.

BARRIO, R., M. J. SHEA, J. CARULLI, K. LIPKOW, U. GAUL et al. (1996) The spaltrelated gene of Drosophila melanogaster is a member of an ancient family, defined by the adjacent, region-specific homeotic gene spalt. Dev Genes Evol 206: 315-325.

BASSON, M., and H. R. HORVITZ (1996) The Caenorhabditis elegans gene sem4 controls neuronal and mesodermal cell development and encodes a zinc finger protein. Genes Dev 10: 1953-1965.

BOHM, J., F. J. KAISER, W. BOROZDIN, R. DEPPING and J. KOHLHASE (2007) Synergistic cooperation of Sall4 and Cyclin D1 in transcriptional repression. Biochem Biophys Res Commun 356: 773-779.

BOHM, J., C. SUSTMANN, C. WILHELM and J. KOHLHASE (2006) SALL4 is directly activated by TCF/LEF in the canonical Wnt signaling pathway. Biochem Biophys Res Commun 348: 898-907.

BOROZDIN, W., D. BOEHM, M. LEIPOLDT, C. WILHELM, W. REARDON et al. (2004) SALL4 deletions are a common cause of Okihiro and acro-renal-ocular syndromes and confirm haploinsufficiency as the pathogenic mechanism. $J$ Med Genet 41: e113.

BOROZDIN, W., K. STEINMANN, B. ALBRECHT, A. BOTTANI, K. DEVRIENDT et al. (2006) Detection of heterozygous SALL1 deletions by quantitative real time PCR proves the contribution of a SALL1 dosage effect in the pathogenesis of Townes-Brocks syndrome. Hum Mutat 27: 211-212.

BOTZENHART, E. M., G. BARTALINI, E. BLAIR, A. F. BRADY, F. ELMSLIE et al. (2007) Townes-Brocks syndrome: twenty novel SALL1 mutations in sporadic and familial cases and refinement of the SALL1 hot spot region. Hum Mutat28: 204-205.

BRASSINGTON, A. M., S. S. SUNG, R. M. TOYDEMIR, T. LE, A. D. ROEDER et al. (2003) Expressivity of Holt-Oram syndrome is not predicted by TBX5 genotype. Am J Hum Genet 73: 74-85.

BRUNETTI, C. R., J. E. SELEGUE, A. MONTEIRO, V. FRENCH, P. M. BRAKEFIELD et al. (2001) The generation and diversification of butterfly eyespot color patterns. Curr Biol 11: 1578-1585.

BUCK, A., L. ARCHANGELO, C. DIXKENS and J. KOHLHASE (2000) Molecular cloning, chromosomal localization, and expression of the murine SALL1 ortholog Sall1. Cytogenet Cell Genet 89: 150-153.

BUCK, A., A. KISPERT and J. KOHLHASE (2001) Embryonic expression of the murine homologue of $S A L L 1$, the gene mutated in Townes-Brocks syndrome. Mech Dev 104: 143-146.

CAMP, E., R. HOPE, R. D. KORTSCHAK, T. C. COX and M. LARDELLI (2003) Expression of three spalt (sa) gene homologues in zebrafish embryos. Dev Genes Evo/213: 35-43.

CAPDEVILA, J., T. TSUKUI, C. RODRIQUEZ ESTEBAN, V. ZAPPAVIGNA and J. C. IZPISUA BELMONTE (1999) Control of vertebrate limb outgrowth by the proximal factor Meis2 and distal antagonism of BMPs by Gremlin. Mo/ Ce//4: 839-849.

CARL, M., and J. WITTBRODT (1999) Graded interference with FGF signalling reveals its dorsoventral asymmetry at the mid-hindbrain boundary. Development 126: 5659-5667.

CHEN, C. K., R. P. KUHNLEIN, K. G. EULENBERG, S. VINCENT, M. AFFOLTER et al. (1998) The transcription factors KNIRPS and KNIRPS RELATED control cell migration and branch morphogenesis during Drosophila tracheal development. Development 125: 4959-4968.

CHIHARA, T., and S. HAYASHI (2000) Control of tracheal tubulogenesis by Wingless signaling. Development 127: 4433-4442.

CHOI, Y., Y. QIN, M. F. BERGER, D. J. BALLOW, M. L. BULYK et al. (2007) Microarray Analyses of Newborn Mouse Ovaries Lacking Nobox. Biol Reprod. 77: 312-319

COOK, O., B. BIEHS and E. BIER (2004) brinker and optomotor-blind act coordinately to initiate development of the L5 wing vein primordium in Drosophila. Development 131: 2113-2124.

COPF, T., N. RABET and M. AVEROF (2006) Knockdown of spalffunction by RNAi causes de-repression of Hox genes and homeotic transformations in the crustacean Artemia franciscana. Dev Biol. 298: 87-94.

CUI, W., N. R. KONG, Y. MA, H. M. AMIN, R. LAI etal. (2006) Differential expression of the novel oncogene, SALL4, in lymphoma, plasma cell myeloma, and acute lymphoblastic leukemia. Mod Pathol. 19: 1585-1592.

DE CELIS, J. F., and R. BARRIO (2000) Function of the spalt/spalt-related gene complex in positioning the veins in the Drosophila wing. Mech Dev 91: 31-41.

DE CELIS, J. F., R. BARRIO and F. C. KAFATOS (1996) A gene complex acting downstream of dpp in Drosophila wing morphogenesis. Nature 381: 421-424.

DE CELIS, J. F., R. BARRIO and F. C. KAFATOS (1999) Regulation of the spalt/ spalt-related gene complex and its function during sensory organ development in the Drosophila thorax. Development 126: 2653-2662.

DEL ALAMO RODRIGUEZ, D., J. TERRIENTE FELIX and F. J. DIAZ-BENJUMEA (2004) The role of the T-box gene optomotor-blind in patterning the Drosophila wing. Dev Bio/268: 481-492.

DENHOLM, B., V. SUDARSAN, S. PASALODOS-SANCHEZ, R. ARTERO, P. LAWRENCE et al. (2003) Dual origin of the renal tubules in Drosophila: mesodermal cells integrate and polarize to establish secretory function. Curr Bio/13: 1052-1057.

DOMINGOS, P. M., S. BROWN, R. BARRIO, K. RATNAKUMAR, B. J. FRANKFORT et al. (2004a) Regulation of R7 and R8 differentiation by the spaltgenes. Dev Bio/273: 121-133.

DOMINGOS, P. M., M. MLODZIK, C. S. MENDES, S. BROWN, H. STELLER et al. (2004b) Spalt transcription factors are required for R3/R4 specification and establishment of planar cell polarity in the Drosophila eye. Development 131 : 5695-5702.

DONG, P. D., J. CHU and G. PANGANIBAN (2000) Coexpression of the homeobox genes Distal-less and homothorax determines Drosophila antennal identity. Development 127: 209-216.

DONG, P. D., S. V. TODI, D. F. EBERL and G. BOEKHOFF-FALK (2003) Drosophila spaltspalt-related mutants exhibit Townes-Brocks' syndrome phenotypes. Proc Natl Acad Sci USA 100: 10293-10298.

DRESSLER, G. R. (2006) The cellular basis of kidney development. Annu Rev Cell Dev Bio/22: 509-529.

ELLING, U., C. KLASEN, T. EISENBERGER, K. ANLAG and M. TREIER (2006) Murine inner cell mass-derived lineages depend on Sall4 function. Proc Natl Acad Sci USA. 103: 16319-16324.

ELSTOB, P. R., V. BRODU and A. P. GOULD (2001) spalt-dependent switching between two cell fates that are induced by the Drosophila EGF receptor. Development 128: 723-732. 
FARRELL, E. R., and A. E. MUNSTERBERG (2000) csa/1 is controlled by a combination of FGF and Wnt signals in developing limb buds. Dev Bio/225: 447-458.

FARRELL, E. R., G. TOSH, E. CHURCH and A. E. MUNSTERBERG (2001) Cloning and expression of $C S A L 2$, a new member of the spaltgene family in chick. Mech Dev 102: 227-230.

FRANCH-MARRO, X., and J. CASANOVA (2002) spalt-induced specification of distinct dorsal and ventral domains is required for Drosophila tracheal patterning. Dev Bio/250: 374-382.

GOMEZ-SKARMETA, J. L., R. DIEZ DEL CORRAL, E. DE LA CALLE-MUSTIENES, D. FERRE-MARCO and J. MODOLELL (1996) Araucan and caupolican, two members of the novel iroquois complex, encode homeoproteins that control proneural and vein-forming genes. Cel/85: 95-105.

GOULD, A. P., P. R. ELSTOB and V. BRODU (2001) Insect oenocytes: a mode system for studying cell-fate specification by Hox genes. J Anat 199: 25-33.

GRANT, K., W. HANNA-ROSE and M. HAN (2000) sem-4promotes vulval cell-fate determination in Caenorhabditis elegans through regulation of lin-39Hox. Dev Bio/224: 496-506.

GUSS, K. A., C. E. NELSON, A. HUDSON, M. E. KRAUS and S. B. CARROLL (2001) Control of a genetic regulatory network by a selector gene. Science292: 1164-1167.

HABANO, W., T. SUGAI, Y. F. JIAO and S. I. NAKAMURA (2007) Novel approach for detecting global epigenetic alterations associated with tumor cell aneuploidy. Int J Cancer. 121: 1487-1493.

HARVEY, S. A., and M. P. LOGAN (2006) sall4 acts downstream of tbx5 and is required for pectoral fin outgrowth. Development 133: 1165-1173.

HASSON, P., N. EGOZ, C. WINKLER, G. VOLOHONSKY, S. JIA et al. (2005) EGFR signaling attenuates Groucho-dependent repression to antagonize Notch transcriptional output. Nat Genet 37: 101-105.

HOLLEMANN, T., R. SCHUH, T. PIELER and R. STICK (1996) Xenopus Xsal-1, a vertebrate homolog of the region specific homeotic gene spalt of Drosophila. Mech Dev 55: 19-32.

IZUMI, K., M. ARAMAKI, T. KIMURA, Y. NAITO, T. UDAKA et al. (2007) Identification of a Prosencephalic-Specific Enhancer of $S A L L$ 1: Comparative Genomic Approach Using the Chick Embryo. Pediatr Res. 61: 660-665.

JAIN, S., A. A. SUAREZ, J. MCGUIRE and H. LIAPIS (2007) Expression profiles of congenital renal dysplasia reveal new insights into renal development and disease. Pediatr Nephrol 22. 962-974.

JURGENS, G. (1988) Head and tail development of the Drosophilaembryo involves spalt, a novel homeotic gene. EMBO J7: 189-196.

KIEFER, S. M., B. W. MCDILL, J. YANG and M. RAUCHMAN (2002) Murine Sall1 represses transcription by recruiting a histone deacetylase complex. J Biol Chem 277: 14869-14876.

KIEFER, S. M., K. K. OHLEMILLER, J. YANG, B. W. MCDILL, J. KOHLHASE et al. (2003) Expression of a truncated Sall1 transcriptional repressor is responsible for Townes-Brocks syndrome birth defects. Hum Mol Genet 12: 2221-2227.

KING, M. W., T. NGUYEN, J. CALLEY, M. W. HARTY, M. C. MUZINICH etal. (2003) Identification of genes expressed during Xenopus laevis limb regeneration by using subtractive hybridization. Dev Dyn 226: 398-409.

KOHLHASE, J., M. ALTMANN, L. ARCHANGELO, C. DIXKENS and W. ENGEL (2000) Genomic cloning, chromosomal mapping, and expression analysis of msal-2. Mamm Genome 11: 64-68.

KOHLHASE, J., D. CHITAYAT, D. KOTZOT, S. CEYLANER, U. G. FROSTER et al. (2005) SALL4 mutations in Okihiro syndrome (Duane-radial ray syndrome), acro-renal-ocular syndrome, and related disorders. Hum Mutat 26: 176-183.

KOHLHASE, J., S. HAUSMANN, G. STOJMENOVIC, C. DIXKENS, K. BINK et al. (1999a) $S A L L 3$, a new member of the human spalt-like gene family, maps to 18q23. Genomics 62: 216-222.

KOHLHASE, J., M. HEINRICH, M. LIEBERS, L. FROHLICH ARCHANGELO, W. REARDON etal. (2002a) Cloning and expression analysis of $S A L L 4$, the murine homologue of the gene mutated in Okihiro syndrome. Cytogenet Genome Res 98: $274-277$

KOHLHASE, J., M. HEINRICH, L. SCHUBERT, M. LIEBERS, A. KISPERT et al. (2002b) Okihiro syndrome is caused by SALL4 mutations. Hum Mol Genet 11 : 2979-2987.

KOHLHASE, J., and L. B. HOLMES (2004) Mutations in SALL4 in malformed father and daughter postulated previously due to reflect mutagenesis by thalidomide. Birth Defects Res A Clin Mol Teratol70: 550-551.

KOHLHASE, J., R. SCHUH, G. DOWE, R. P. KUHNLEIN, H. JACKLE et al. (1996) Isolation, characterization, and organ-specific expression of two novel human zinc finger genes related to the Drosophila gene spalt. Genomics 38: 291-298.

KOHLHASE, J., P. E. TASCHNER, P. BURFEIND, B. PASCHE, B. NEWMAN et al. (1999b) Molecular analysis of SALL1 mutations in Townes-Brocks syndrome. Am J Hum Genet 64: 435-445.

KOHLHASE, J., A. WISCHERMANN, H. REICHENBACH, U. FROSTER and W. ENGEL (1998) Mutations in the $S A L L 1$ putative transcription factor gene cause Townes-Brocks syndrome. Nat Genet 18: 81-83.

KOSHIBA-TAKEUCHI, K., J. K. TAKEUCHI, E. P. ARRUDA, I. S. KATHIRIYA, R MO et al. (2006) Cooperative and antagonistic interactions between Sall4 and Tbx5 pattern the mouse limb and heart. Nat Genet 38: 175-183.

KOSTER, R., R. STICK, F. LOOSLI and J. WITTBRODT (1997) Medaka spaltacts as a target gene of hedgehog signaling. Development 124: 3147-3156.

KUHNLEIN, R. P., G. BRONNER, H. TAUBERT and R. SCHUH (1997) Regulation of Drosophila spaltgene expression. Mech Dev66: 107-118.

KUHNLEIN, R. P., G. FROMMER, M. FRIEDRICH, M. GONZALEZ-GAITAN, A. WEBER et al. (1994) spalt encodes an evolutionarily conserved zinc finger protein of novel structure which provides homeotic gene function in the head and tail region of the Drosophila embryo. Embo J13: 168-179.

KÜHNLEIN, R. P., and R. SCHUH (1996) Dual function of the region-specific homeotic gene spalt during Drosophilatracheal system development. Development 122: 2215-2223.

LAUBERTH, S. M., and M. RAUCHMAN (2006) A conserved 12-amino Acid motif in sall1 recruits the nucleosome remodeling and deacetylase corepressor complex. J Biol Chem 281: 23922-23931.

LAUBERTH, S. M., BILYEU, A. C., FIRULLI, B. A., KROLL, K.L., and M. RAUCHMAN (2007) A phosphomimetic mutation in the Sall1 repression motif disrupts recruitment of the nucleosome remodeling and deacetylase complex and repression of Gbx2. J Biol Chem 282: 34858-34868.

LI, C. M., M. GUO, A. BORCZUK, C. A. POWELL, M. WEl et al. (2002) Gene expression in Wilms' tumor mimics the earliest committed stage in the metanephric mesenchymal-epithelial transition. Am J Patho/160: 2181-2190.

LI, D., K. DOWER, Y. MA, Y. TIAN and T. L. BENJAMIN (2001) A tumor host range selection procedure identifies $p 150$ (sal2) as a target of polyoma virus large T antigen. Proc Nat/ Acad Sci USA 98: 14619-14624.

LI, D., Y. TIAN, Y. MA and T. BENJAMIN (2004) p150 (Sal2) is a p53-independent regulator of $p 21$ (WAF1/CIP). Mol Cell Biol24: 3885-3893.

LIAPIS, H. (2003) Biology of congenital obstructive nephropathy. Nephron Exp Nephro/93: e87-91.

LIU, H., A. S. ADLER, E. SEGAL and H. Y. CHANG (2007) A Transcriptional Program Mediating Entry into Cellular Quiescence. PLOS Genet 3: e91.

MA, Y., L. CHAI, S. C. CORTEZ, E. G. STOPA, M. M. STEINHOFF et al. (2002) $S A L L 1$ expression in the human pituitary-adrenal/gonadal axis. J Endocrinol 173. $437-448$

MA, Y., W. CUI, J. YANG, J. QU, C. DI et al. (2006) SALL4, a novel oncogene, is constitutively expressed in human acute myeloid leukemia (AML) and induces AML in transgenic mice. Blood 108: 2726-2735.

MA, Y., D. B. SINGER, A. GOZMAN, D. FORD, L. CHAl etal. (2001) Hsal 1 is related to kidney and gonad development and is expressed in Wilms tumor. Pediatr Nephro/16: 701-709.

METZGER, R. J., and M. A. KRASNOW (1999) Genetic control of branching morphogenesis. Science 284: 1635-1639.

MIERTUS, J., W. BOROZDIN, V. FRECER, G. TONINI, S. BERTOK et al. (2006) A SALL4 zinc finger missense mutation predicted to result in increased DNA binding affinity is associated with cranial midline defects and mild features of Okihiro syndrome. Hum Genet 119: 154-161.

MILAN, M., L. PEREZ and S. M. COHEN (2002) Short-range cell interactions and cell survival in the Drosophila wing. Dev Cel/2: 797-805.

MITANI, S., H. DU, D. H. HALL, M. DRISCOLL and M. CHALFIE (1993) Combinatorial control of touch receptor neuron expression in Caenorhabditis elegans. Development 119: 773-783.

MOLLEREAU, B., M. DOMINGUEZ, R. WEBEL, N. J. COLLEY, B. KEUNG et al. 
(2001) Two-step process for photoreceptor formation in Drosophila. Nature 412: 911-913.

MONTEIRO, A., G. GLASER, S. STOCKSLAGER, N. GLANSDORP and D. RAMOS (2006) Comparative insights into questions of lepidopteran wing pattern homology. BMC Dev Bio/6: 52.

NEFF, A. W., M. W. KING, M. W. HARTY, T. NGUYEN, J. CALLEY et al. (2005) Expression of Xenopus XISALL4 during limb development and regeneration. Dev Dyn 233: 356-367.

NETZER, C., S. K. BOHLANDER, M. HINZKE, Y. CHEN and J. KOHLHASE (2006) Defining the heterochromatin localization and repression domains of SALL1. Biochim Biophys Acta 1762: 386-391.

NETZER, C., S. K. BOHLANDER, L. RIEGER, S. MULLER and J. KOHLHASE (2002) Interaction of the developmental regulator SALL1 with UBE2I and SUMO-1. Biochem Biophys Res Commun 296: 870-876.

NETZER, C., L. RIEGER, A. BRERO, C. D. ZHANG, M. HINZKE et al. (2001) SALL1, the gene mutated in Townes-Brocks syndrome, encodes a transcriptional repressor which interacts with TRF1/PIN2 and localizes to pericentromeric heterochromatin. Hum Mol Genet 10: 3017-3024.

NIELSEN, T. O., F. D. HSU, J. X. O'CONNELL, C. B. GILKS, P. H. SORENSEN et al. (2003) Tissue microarray validation of epidermal growth factor receptor and SALL2 in synovial sarcoma with comparison to tumors of similar histology. $\mathrm{Am}$ $J$ Patho/ 163: 1449-1456.

NISHINAKAMURA, R., Y. MATSUMOTO, K. NAKAO, K. NAKAMURA, A. SATO et al. (2001) Murine homolog of $S A L L 1$ is essential for ureteric bud invasion in kidney development. Development 128: 3105-3115.

NISHINAKAMURA, R., and K. OSAFUNE (2006) Essential roles of sal/family genes in kidney development. J Physiol Sci56: 131-136.

OHGANE, J., T. WAKAYAMA, S. SENDA, Y. YAMAZAKI, K. INOUE et al. (2004) The Sal/3 locus is an epigenetic hotspot of aberrant DNA methylation associated with placentomegaly of cloned mice. Genes Cells 9: 253-260.

ONAI, T., N. SASAI, M. MATSUI and Y. SASAI (2004) Xenopus XsalF: anterior neuroectodermal specification by attenuating cellular responsiveness to $\mathrm{Wnt}$ signaling. Dev Cel/7: 95-106.

ONUMA, Y., R. NISHINAKAMURA, S. TAKAHASHI, T. YOKOTA and M. ASASHIMA (1999) Molecular cloning of a novel Xenopus spalt gene (Xsat-3). Biochem Biophys Res Commun 264: 151-156.

OSAFUNE, K., M. TAKASATO, A. KISPERT, M. ASASHIMA and R. NISHINAKAMURA (2006) Identification of multipotent progenitors in the embryonic mouse kidney by a novel colony-forming assay. Development 133: 151161.

OTT, T., K. H. KAESTNER, A. P. MONAGHAN and G. SCHUTZ (1996) The mouse homolog of the region specific homeotic gene spalt of Drosophila is expressed in the developing nervous system and in mesoderm-derived structures. Mech Dev56: 117-128.

OTT, T., M. PARRISH, K. BOND, A. SCHWAEGER-NICKOLENKO and A. P. MONAGHAN (2001) A new member of the spalt like zinc finger protein family, Msat 3 , is expressed in the CNS and sites of epithelial/mesenchymal interaction. Mech Dev 101: 203-207.

PARRISH, M., T. OTT, C. LANCE-JONES, G. SCHUETZ, A. SCHWAEGERNICKOLENKO et al. (2004) Loss of the Sal/3 gene leads to palate deficiency, abnormalities in cranial nerves, and perinatal lethality. Mol Cel/ Bio/24: 71027112.

PENNACCHIO, L. A., N. AHITUV, A. M. MOSES, S. PRABHAKAR, M. A. NOBREGA et al. (2006) In vivo enhancer analysis of human conserved non-coding sequences. Nature 444: 499-502.

PEREIRA, L., F. YI and B. J. MERRILL (2006) Repression of Nanog gene transcription by Tcf3 limits embryonic stem cell self-renewal. Mo/ Cel/ Bio/26: 7479-7491.

PHOTOS, A., A. GUTIERREZ and R. J. SOMMER (2006) sem-4/spalt and egl-17/ FGF have a conserved role in sex myoblast specification and migration in $P$. pacificus and C. elegans. Dev Bio/293: 142-153.

POLADIA, D. P., K. KISH, B. KUTAY, D. HAINS, H. KEGG et al. (2006) Role of fibroblast growth factor receptors 1 and 2 in the metanephric mesenchyme. Dev Bio/291: 325-339.

POWELL, C. M., and R. C. MICHAELIS (1999) Townes-Brocks syndrome. J Med Genet 36: 89-93.
RIBEIRO, C., M. NEUMANN and M. AFFOLTER (2004) Genetic control of cell intercalation during tracheal morphogenesis in Drosophila. Curr Biol 14: 2197-2207.

ROMERO, D. G., S. RILLI, M. W. PLONCZYNSKI, L. L. YANES, M. Y. ZHOU et al. (2007) Adrenal Transcription Regulatory Genes Modulated by Angiotensin II and Their Role in Steroidogenesis. Physiol Genomics. 30: 26-34.

RUIZ-GOMEZ, M., and J. MODOLELL (1987) Deletion analysis of the achaetescute locus of Drosophila melanogaster. Genes Dev1: 1238-1246.

RUSTEN, T. E., R. CANTERA, J. URBAN, G. TECHNAU, F. C. KAFATOS et al. (2001) Spalt modifies EGFR-mediated induction of chordotonal precursors in the embryonic PNS of Drosophila promoting the development of oenocytes. Development 128: 711-722.

SAKAKI-YUMOTO, M., C. KOBAYASHI, A. SATO, S. FUJIMURA, Y. MATSUMOTO et al. (2006) The murine homolog of $S A L L 4$, a causative gene in Okihiro syndrome, is essential for embryonic stem cell proliferation, and cooperates with Sall1 in anorectal, heart, brain and kidney development. Development133 3005-3013.

SATO, A., S. KISHIDA, T. TANAKA, A. KIKUCHI, T. KODAMA et al. (2004) Sall1, a causative gene for Townes-Brocks syndrome, enhances the canonical Wnt signaling by localizing to heterochromatin. Biochem Biophys Res Commun319: 103-113.

SATO, A., Y. MATSUMOTO, U. KOIDE, Y. KATAOKA, N. YOSHIDA et al. (2003) Zinc finger protein sall2 is not essential for embryonic and kidney development. $\mathrm{Mol}$ Cell Bio/23: 62-69.

SHEA, M. J., D. L. KING, M. J. CONBOY, B. D. MARIANI and F. C. KAFATOS (1990) Proteins that bind to Drosophila chorion cis-regulatory elements: a new $\mathrm{C} 2 \mathrm{H} 2$ zinc finger protein and a $\mathrm{C} 2 \mathrm{C} 2$ steroid receptor-like component. Genes Dev 4: $1128-1140$

SI DONG, P. D., S. V. TODI, D. F. EBERL and G. BOEKHOFF-FALK (2003) Drosophila spalt/spalt-related mutants exhibit Townes-Brocks' syndrome phenotypes. Proc. Natl. Acad. Sci. USA 100: 10293-10298.

SURKA, W. S., KOHLHASE, J., NEUNERT, C. E., SCHNEIDER, D. S. AND PROUD, V. K. (2001). Unique family with Townes-Brocks syndrome, SALL1 mutation, and cardiac defects. Am J Med Genet 102: 250-257.

SWEETMAN, D., and A. MUNSTERBERG (2006) The vertebrate spalt genes in development and disease. Dev Biol. 293: 285-293.

SWEETMAN, D., T. SMITH, E. R. FARRELL, A. CHANTRY and A. MUNSTERBERG (2003) The conserved glutamine-rich region of chick csal1 and csal3 mediates protein interactions with other spalt family members. Implications for TownesBrocks syndrome. J Biol Chem 278: 6560-6566.

TOKER, A. S., Y. TENG, H. B. FERREIRA, S. W. EMMONS and M. CHALFIE (2003) The Caenorhabditis elegans spalt-like gene sem-4 restricts touch cell fate by repressing the selector Hox gene eg/-5and the effector gene mec-3. Development 130: 3831-3840

TROTT, R. L., M. KALIVE, U. KARANDIKAR, R. RUMMER, C. P. BISHOP et al. (2001) Identification and characterization of proteins that interact with Drosophila melanogaster protein kinase CK2. Mol Cell Biochem 227: 91-98.

WAGNER-BERNHOLZ, J. T., C. WILSON, G. GIBSON, R. SCHUH and W. J. GEHRING (1991) Identification of target genes of the homeotic gene Antennapedia by enhancer detection. Genes Dev 5: 2467-2480.

WAPPNER, P., L. GABAY and B. Z. SHILO (1997) Interactions between the EGF receptor and DPP pathways establish distinct cell fates in the tracheal placodes. Development 124: 4707-4716.

WARREN, M., W. WANG, S. SPIDEN, D. CHEN-MURCHIE, D. TANNAHILL et al. (2007) A Sall 4 mutant mouse model useful for studying the role of Sall 4 in early embryonic development and organogenesis. Genesis 45: 51-58.

WEATHERBEE, S. D., G. HALDER, J. KIM, A. HUDSON and S. CARROLL (1998) Ultrabithorax regulates genes at several levels of the wing-patterning hierarchy to shape the development of the Drosophilahaltere. Genes Dev12: 1474-1482.

WINTER, S. E., and G. CAMPBELL (2004) Repression of Dpp targets in the Drosophila wing by Brinker. Development 131: 6071-6081.

WU, Q., X. CHEN, J. ZHANG, Y. H. LOH, T. Y. LOW et al. (2006) Sall4 Interacts with Nanog and Co-occupies Nanog Genomic Sites in Embryonic Stem Cells. J Biol Chem 281: 24090-24094.

YAMAMOTO, M., L. CUI, K. JOHKURA, K. ASANUMA, Y. OKOUCHI et al. (2006) Branching ducts similar to mesonephric ducts or ureteric buds in teratomas 
originating from mouse embryonic stem cells. Am J Physiol Renal Physiol 290. F52-60.

YAMASHITA, K., A. SATO, M. ASASHIMA, P. C. WANG and R. NISHINAKAMURA (2007) Mouse homolog of SALL1, a causative gene for Townes-Brocks syndrome, binds to $A / T$-rich sequences in pericentric heterochromatin via its $C$ terminal zinc finger domains. Genes Cells 12: 171-182.
YANG, J., L. CHAI, F. LIU, L. M. FINK, P. LIN et al. (2007) Bmi-1 is a target gene for SALL4 in hematopoietic and leukemic cells. Proc Natl Acad Sci USA 104: 10494-10499.

ZHANG, J., W. L. TAM, G. Q. TONG, Q. WU, H. Y. CHAN et al. (2006) Sall4 modulates embryonic stem cell pluripotency and early embryonic development by the transcriptional regulation of Pou5f1. Nat Cell Bio/8: 1114-1123.

\section{Further Related Reading, published previously in the Int. J. Dev. Biol.}

See our recent Special Issue Fertilization, in honor of David L. Garbers and edited by Paul M. Wassarman and Victor D. Vacquier at: http://www.ijdb.ehu.es/web/contents.php?vol=52\&issue=5-6

See our recent Special Issue Limb Development edited by Juan Hurlé and Juan Carlos Izpisua-Belmonte at: http://www.ijdb.ehu.es/web/contents.php?vol=46\&issue $=7$

\section{Development of Johnston's organ in Drosophila}

Daniel F. Eberl and Grace Boekhoff-Falk

Int. J. Dev. Biol. (2007) 51: 679-687

\section{Expression of csal1 in pre limb-bud chick embryos}

Dylan Sweetman, Terence G. Smith, Elizabeth R. Farrell and Andrea Münsterberg Int. J. Dev. Biol. (2005) 49: 427-430

Developmental basis for vein pattern variations in insect wings. José F De Celis and Fernando J Diaz-Benjumea

Int. J. Dev. Biol. (2003) 47: 653-663

Positioning and differentiation of veins in the Drosophila wing. J F De Celis

Int. J. Dev. Biol. (1998) 42: 335-343

Regulation of cell migration during tracheal development in Drosophila melanogaster. Valérie Petit, Carlos Ribeiro, Andreas Ebner and Markus Affolter Int. J. Dev. Biol. (2002) 46: 125-132

The ash2 gene is involved in Drosophila wing development. Montserrat Amorós, Montserrat Corominas, Peter Deák and Florenci Serras Int. J. Dev. Biol. (2002) 46: 321-324

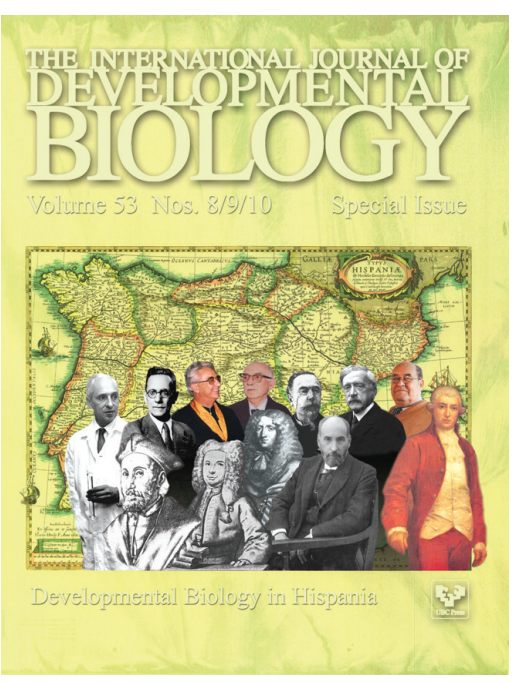

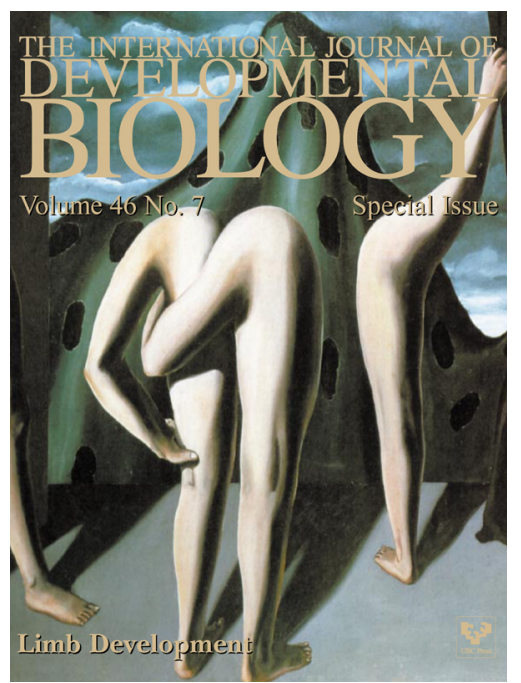

5 yr ISI Impact Factor $(2008)=3.271$

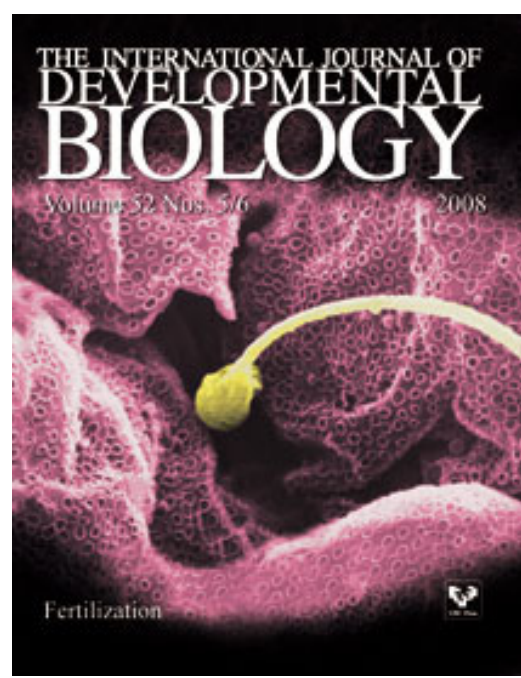

